\title{
Toxicogenomic analysis of exposure to TCDD, PCB126 and PCB153: identification of genomic biomarkers of exposure to AhR ligands
}

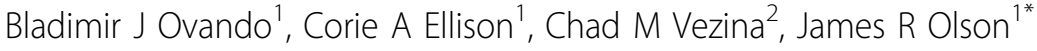

\begin{abstract}
Background: Two year cancer bioassays conducted by the National Toxicology Program have shown chronic exposure to dioxin-like compounds (DLCS) to lead to the development of both neoplastic and non-neoplastic lesions in the hepatic tissue of female Sprague Dawley rats. Most, if not all, of the hepatotoxic effects induced by DLC's are believed to involve the binding and activation of the transcription factor, the aryl hydrocarbon receptor (AhR). Toxicogenomics was implemented to identify genomic responses that may be contributing to the development of hepatotoxicity in rats.

Results: Through comparative analysis of time-course microarray data, unique hepatic gene expression signatures were identified for the DLCs, 2,3,7,8-tetrachlorodibenzo-p-dioxin (TCDD) (100 ng/kg/day) and 3,3,4,4,5-pentachlorobiphenyl

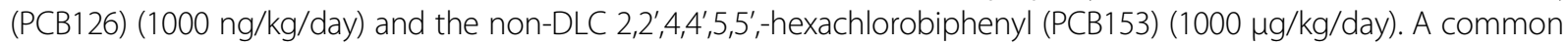
time independent signature of $41 \mathrm{AhR}$ genomic biomarkers was identified which exhibited at least a 2-fold change in expression following subchronic (13-wk) and chronic (52-wk) p.o. exposure to TCDD and PCB126, but not the non DLC, PCB153. Real time gPCR analysis validated that 30 of these genes also exhibited at least a 2-fold change in hepatic expression at $24 \mathrm{hr}$ following a single exposure to TCDD $(5 \mu \mathrm{g} / \mathrm{kg}$, po). Phenotypic anchoring was conducted which identified forty-six genes that were differently expressed both following chronic p.o. exposure to DLCs and in previously reported studies of cholangiocarcinoma or hepatocellular adenoma.

Conclusions: Together these analyses provide a comprehensive description of the genomic responses which occur in rat hepatic tissue with exposure to AhR ligands and will help to isolate those genomic responses which are contributing to the hepatotoxicity observed with exposure to DLCs. In addition, the time independent gene expression signature of the AhR ligands may assist in identifying other agents with the potential to elicit dioxin-like hepatotoxic responses.
\end{abstract}

\section{Background}

Dioxin-like compounds (DLCs) such as polychlorinated biphenyls (PCBs) and polychlorinated dibenzo-p-dioxins (PCDDs) are prevalent contaminants which pose a risk to both public health and the environment. Exposure to PCBs and PCDDs has been associated with numerous adverse biological effects including reproductive toxicity, dermatotoxicity, immunotoxicity, developmental toxicity, neurotoxicity, carcinogenesis and hepatotoxicity [1-5]. The carcinogenic and hepatotoxic effects of DLCs have

\footnotetext{
* Correspondence: jolson@buffalo.edu

'Department of Pharmacology and Toxicology, School of Medicine and Biomedical Sciences, University at Buffalo, Buffalo, New York 14214, USA Full list of author information is available at the end of the article
}

\footnotetext{
Fullist of author information is available at the end of the article
}

been shown to be gender dependent, with female rats being more susceptible than male rats [6]. The DLCs, 2,3,7,8-tetrachlorodibenzo-p-dioxin (TCDD) and 3,3',4,4',5-pentachlorobiphenyl (PCB126); and the nonDLC 2,2',4,4',5,5',-hexachlorobiphenyl (PCB153) were investigated by the National Toxicology Program in a two-year cancer bioassay evaluating their hepatotoxic and carcinogenic properties in female Sprague-Dawley (SD) rats $[4,5,7,8]$. Following 104 weeks of chronic p.o. exposure to TCDD (100 ng/kg/day) or PCB126 (1000 ng/ $\mathrm{kg} /$ day), a significant and similar increase in the incidence and range of non-neoplastic and neoplastic lesions were observed in the livers of female rats (Table 1) [4,5]. The non-neoplastic lesions included, but were not

C 2010 Ovando et al; licensee BioMed Central Ltd. This is an Open Access article distributed under the terms of the Creative Commons Attribution License (http://creativecommons.org/licenses/by/2.0), which permits unrestricted use, distribution, and reproduction in any medium, provided the original work is properly cited. 
Table 1 Neoplastic and non-neoplastic lesions observed in hepatic tissue of female Sprague-Dawley rats following 104 weeks of chronic p.o. exposure

\begin{tabular}{|c|c|c|c|c|c|}
\hline & $\begin{array}{l}100 \mathrm{ng} / \mathrm{kg} / \text { day } \\
\text { TCDD }\end{array}$ & $\begin{array}{l}30 \mathrm{ng} / \mathrm{kg} / \text { day } \\
\text { PCB126 }\end{array}$ & $\begin{array}{l}300 \mathrm{ng} / \mathrm{kg} / \mathrm{day} \\
\text { PCB126 }\end{array}$ & $\begin{array}{l}1000 \mathrm{ng} / \mathrm{kg} / \text { day } \\
\text { PCB126 }\end{array}$ & $\begin{array}{l}1000 \mu \mathrm{g} / \mathrm{kg} / \mathrm{day} \\
\text { PCB153 }\end{array}$ \\
\hline $\begin{array}{l}\text { Number of Rats } \\
\text { Examined }\end{array}$ & 53 & 55 & 53 & 53 & 53 \\
\hline Hepatocyte Hypertrophy & $52^{* * a}$ & $23^{* *}$ & $42^{* * a}$ & $49^{* * a}$ & $39^{* * a}$ \\
\hline $\begin{array}{l}\text { Multinucleated } \\
\text { Hepatocytes }\end{array}$ & $51 *$ b & 2 & $19^{* *}$ & $49^{* * b}$ & NA \\
\hline Fatty Change, Diffuse & $48^{* * b}$ & 7 & $30^{* *}$ & $47^{* * \mathrm{~b}}$ & $21^{* *}$ \\
\hline Bile Duct Hyperplasia & $53^{* * b}$ & 7 & $14^{* *}$ & $45^{* * \mathrm{~b}}$ & 10 \\
\hline Bile Duct Cyst & $21^{* *}$ & 6 & 3 & $12^{*}$ & NA \\
\hline Oval Cell, Hyperplasia & $53^{* *}$ & 1 & $10^{* *}$ & $40^{* *}$ & NA \\
\hline Necrosis & $17^{* *}$ & 2 & 11 & $17^{* *}$ & NA \\
\hline Pigmentation & $53^{* * b}$ & $11^{* *}$ & $48^{* * b}$ & $48^{* * \mathrm{~b}}$ & 5 \\
\hline Eosiniphilic Focus & $44^{* *}$ & 10 & 17 & 17 & NA \\
\hline Inflammation & $49^{* *}$ & 40 & $51^{* *}$ & $51^{* *}$ & NA \\
\hline Nodular Hyperplasia & $36^{* *}$ & NA & 3 & $39 * *$ & 1 \\
\hline Portal Fibrosis & $27^{* *}$ & NA & 2 & $10^{* *}$ & NA \\
\hline Cholangiofibrosis & $31^{* *}$ & 1 & 3 & $22^{* *}$ & 1 \\
\hline Toxic Hepatopathy & $53^{* * b}$ & $6^{*}$ & $39^{* *}$ & $49^{* * b}$ & NA \\
\hline Hepatocholangioma & $17^{* *}$ & NA & NA & 3 & 2 \\
\hline Hepatocellular Adenoma & $13^{* *}$ & 2 & 2 & $7^{*}$ & NA \\
\hline Cholangiocarcinoma & $25^{* *}$ & NA & $5^{*}$ & $22^{* *}$ & NA \\
\hline
\end{tabular}

Shown are the number of animals in each treatment group which exhibit the indicated liver pathology following exposure to TCDD (100 ng/kg/day), PCB126 (30, 300 or $1000 \mathrm{ng} / \mathrm{kg} /$ day) or PCB153 $\left(1000 \mu \mathrm{g} / \mathrm{kg} /\right.$ day). Data acquired from the National Toxicology Program $[4,5,8]$. ${ }^{a}$ Response also significantly increased ( $p \leq$ $0.01)$ following 13 and 52 weeks of exposure; ${ }^{b}$ Response also significantly increased $(p \leq 0.01)$ following 52 weeks of exposure; ${ }^{*}$ Statistically significant when compared to control with $\mathrm{p}$-value $\leq 0.05$; * Statistically significant when compared to control with $\mathrm{p}$-value $\leq 0.01 ; \mathrm{NA}$ - not available.

exclusive to, hepatocyte hypertrophy, pigmentation, bile duct hyperplasia, oval cell hyperplasia, fatty diffuse change, necrosis, inflammation and cholangiofibrosis. The neoplastic lesions included hepatocellular adenoma and cholangiocarcinoma. A significant increase in the incidence of 6 of these non-neoplastic lesions and no neoplastic lesions were also observed following 52 weeks of exposure to TCDD or PCB126, while only hepatocyte hypertrophy was observed following 13 weeks of exposure (Table 1). Thus, the range of hepatotoxic responses to these DLCs is directly dependent on the duration of exposure. In comparison, chronic exposure (104 weeks) to the non-DLC PCB153 $(1000 \mu \mathrm{g} / \mathrm{kg} /$ day $)$ only caused a significant increase in the incidence of two non-neoplastic lesions (hepatocyte hypertrophy and diffuse fatty change) and did not lead to the formation of neoplasia (Table 1) [8].

Most, if not all, of the hepatotoxic effects induced by DLCs are believed to involve the binding and activation of the aryl hydrocarbon receptor (AhR). Ligand activation of the AhR induces changes in gene expression and function which are believed to be the major contributing factor to the development of hepatotoxicity, carcinogenicity and other toxic responses of DLCs. DLC-induced AhR-independent genomic and cellular responses have also been reported $[9,10]$, however, these responses likely do not play a major role in the development of hepatotoxicity induced by DLCs. The importance of the AhR in DLC-induced toxicity has been determined in acute studies conducted with female AhR knockout mice. Toxic effects that were observed in wild type mice but were absent in AhR knockout mice, included wasting syndrome, thymic atrophy, lipid accumulation in hepatocytes (diffuse fatty change) and liver hypertrophy $[11,12]$. Acute TCDD toxicity is also gender, species and strain specific. Following acute exposure to TCDD, female Sprague Dawley rats exhibit a greater down-regulation in gene expression compared to male rats [13]. Sprague Dawley rats and C57BL/6 mice exhibit different hepatic gene expression profiles following acute TCDD exposure with rat-specific gene responses being associated with lipid metabolism and cell growth while mouse-specific responses are involved in immune function and lipid uptake/metabolism [14]. Long-Evans rats and $\mathrm{Han} / \mathrm{Wistar}$ rats exhibit a 1000-fold difference in sensitivity to acute TCDD lethality [15] which is attributed to a point mutation in the AhR protein of Han/ Wistar rats [16]. This suggests that the acute toxic effects of TCDD are dependent on AhR functionality, gender, species and strain, and suggest that the chronic toxic effects of DLCs are also mediated through persistent AhR activation. 
Previous work from our laboratory has surveyed hepatic gene expression in response to AhR ligands and non-ligands following acute and 13 weeks of exposure, which were associated with liver hypertrophy in the absence of other hepatotoxic effects [13,17]. Although these studies have led to a better understanding of the acute and subchronic genomic responses to DLCs, the evaluation of hepatic gene expression following chronic exposure to DLCs is needed to effectively identify genomic factors that may be contributing to the hepatotoxic effects of these toxins which are observed following 52 and 104 weeks of exposure (see Table 1). Building on previous microarray experiments, comparative analysis was conducted between microarray data from subchronic (13 weeks) and chronic (52 weeks) time-points to identify genomic biomarkers that are sustained throughout chronic exposure. Genomic biomarkers that were shared by TCDD and PCB126, but not PCB153, were further analyzed for their acute responsiveness to ascertain a subset of genes which may serve as time-independent genomic biomarkers of exposure to AhR ligands in the female SD rat model. Finally, to relate differential hepatic gene expression to the liver pathology observed with chronic exposure to DLCs, phenotypic anchoring was conducted to associate differentially expressed genes with hepatocellular adenoma and cholangiocarcinoma. Together these analyses will provide a comprehensive description of the genomic responses which occur in rat hepatic tissue with subchronic and chronic exposure to AhR ligands and will help to isolate those genomic responses which are contributing to the hepatotoxicity observed with chronic exposure to DLCs.

\section{Methods}

\section{Animal Exposures and Procurement of Liver Tissue}

Liver tissues were obtained from the National Toxicology Program (NTP) 2-year cancer bioassay investigating the relative carcinogenic potencies of the AhR ligands TCDD and PCB126; and the non-ligand PCB153 [4,5,8]. Female $\mathrm{SD}$ rats were exposed 5 days a wk via oral gavage to toxicologically equivalent doses of TCDD (100 ng/kg/day) (Toxic equivalence factor $(\mathrm{TEF})=1.0)$, PCB126 (30 ng, $300 \mathrm{ng}$ or $1000 \mathrm{ng} / \mathrm{kg} /$ day $)(\mathrm{TEF}=0.1), \mathrm{PCB} 153(1000$ $\mu \mathrm{g} / \mathrm{kg} /$ day) $(\mathrm{TEF}=0.0)$ or a vehicle control of corn oil: acetone (99:1). Rats were exposed to these compounds for $13 \mathrm{wks}$ (subchronic exposure) or $52 \mathrm{wks}$ (chronic exposure). TEFs were determined using the 2005 TEF recommendations provided by the World Health Organization [18]. Liver tissue was also harvested from female $\mathrm{SD}$ rats at $24 \mathrm{hr}$ following a single exposure to TCDD (5 $\mu \mathrm{g} / \mathrm{kg}, \mathrm{po})$. This exposure was conducted to identify early responsive genes which were also shown to be differentially expressed (up- or down-) following exposures to DLCs. This acute dose of TCDD has been previously shown to result in hepatic tissue concentrations of dioxin similar to those observed with subchronic and chronic exposure [13]. All procedures were carried out with the approval of the University at Buffalo Institutional Animal Care and Use Committee (PMY14098Y).

\section{RNA Isolation and Hybridization}

The storage and processing of liver samples was described earlier by Vezina et al. 2004. Following storage at $-80^{\circ} \mathrm{C}$, liver tissues were disrupted by homogenization and total RNA was isolated with the Qiagen RNeasy kit (Qiagen Inc., Valencia, CA). RNA integrity was assessed using the Agilent Bioanalyzer 2100 (Agilent Technologies, Palo Alto, CA). High quality RNA was transformed into biotinylated cRNA by the Roswell Park Cancer Institute Gene Expression Facility (Buffalo, NY) and hybridized to RGU34A GeneChips (Affymetrix, Santa Clara, CA) and scanned with the Affymetrix 428 scanner.

\section{Gene Microarray Data Analysis}

Probe-level data from cell intensity files were background subtracted and normalized by the gc-Robust Multiarray Analysis (gcRMA) method using ArrayAssist ${ }^{\circ}$ (Stratagene, CA). Absolute fold changes and t-test statistics (including Benjamini-Hochberg false discovery rate (FDR) corrections) were calculated using ArrayAssist ${ }^{\circ}$. Probe-sets were filtered to identify those genes which exhibited a change in expression (up- or down-) of at least 2 -fold and a t-test $\mathrm{p}$-value $\leq 0.05$ between treated $(\mathrm{n}=3)$ and control $(\mathrm{n}=3)$ groups. Comparative analysis was conducted using Microsoft excel (Microsoft Corporation, Redmond, WA) to further filter the data and identify genes that exhibited statistically significant change ( $\geq 2$-fold) with two or more toxicants. Gene annotation and gene symbols were obtained through the Affymetrix NetAff ${ }^{\mathrm{Tm}}$ Analysis Center Software. Heat maps were constructed using TIGR Microarray Experiment Viewer 4.0 [19]. Student t-tests and ANOVA analysis with the post-hoc Tukey test were conducted between treatment groups using Minitab ${ }^{\text {тм }}$ (Minitab Inc., State College, PA). A complete summary of gene microarray data is available through the Gene Expression Omnibus at the National Center for Biotechnology Information at http://www.ncbi.nlm.nih.gov/geo/ as accession numbers GSE5789 (13 week microarray data) and GSE22263 (52 week microarray data).

\section{Quantitative Real-time PCR analysis}

Quantitative real-time polymerase chain reaction (qPCR) validated the hepatic expression of AhR genomic biomarkers in livers from rats at $24 \mathrm{hr}$ following exposure to TCDD $(5 \mu \mathrm{g} / \mathrm{kg}$, po). Primers were selected from Entrez Gene rat gene reference sequences using Primer3 
software [20]. The parameters for primer selection were described previously [17] and primer sequences are listed in additional file 1. Real-time qPCR was conducted on hepatic cDNA using the IQ SYBR green supermix kit (Bio-Rad Laboratories, Hercules, CA) as described previously in Ovando et al. (2006). Statistical comparisons of control vs. treated groups was performed with a 2-sample t-test using Minitab 15 statistical software (Minitab Inc., State College, PA)

\section{Identification of Dioxin Response Elements (DREs)}

Gene regulatory regions spanning 5000 bp above and $1000 \mathrm{bp}$ below the transcriptional start site of target genes were obtained from the University of California, Santa Cruz, Genome Browser using Entrez Gene GeneID numbers. All obtained sequences were analyzed for core DRE sequences (5'-GCGTG-3') using MatInspector (Genomatix Software GmbH, Munchen, Germany). Putative DREs were those with a core similarity of 1.0 and matrix similarity equal to or greater than the optimized matrix threshold [21].

\section{Phenotypic Anchoring of Gene Expression Data}

Changes in gene expression associated with TCDD, PCB126 and PCB153 exposure were compared with changes in gene expression associated with rat hepatocellular adenoma (HCA) [22], human HCA [23] and human intrahepatic cholangiocarcinoma (ICC) [24,25]. Eightyone percent of the human HCA tumors were from males [23] while 52\% [24] and 41\% [25] of the human ICC tumors were from males. Our approach was limited in that the HCA and ICC expression data was not reported on a gender specific basis thus preventing us from identifying shared gene responses based on gender. Ortholog identification and gene annotation of gene array data obtained from published studies was accomplished using ArrayTrack (Food and Drug Administration, NTCR) and/or NetAffix ${ }^{\text {mix }}$ (Affymetrix Inc.) [26].

\section{Results}

\section{Dose-response Analysis of Hepatic Gene Expression} following Chronic Exposure to $30 \mathrm{ng}, 300 \mathrm{ng}$ and $1000 \mathrm{ng} / \mathrm{kg} /$ day PCB126

Increases in the incidence of non-neoplastic and neoplastic hepatic lesions were observed with increasing dose and duration of exposure to PCB126 (Table 1) [5]. To evaluate the effect of increasing dose of PCB126 on hepatic gene expression, microarray analysis was conducted on hepatic tissue of female SD rats following 52 weeks of chronic exposure to $30 \mathrm{ng}, 300 \mathrm{ng}$ and 1000 ng/kg/day PCB126. Gene array analysis showed a positive trend between PCB126 dose and the number of genes differentially expressed (Table 2). In addition, the magnitude of differential expression of several genes also increased with increasing dose of PCB126 (additional files 2, 3 and 4). Sixteen genes were identified which exhibited altered expression at all three doses (Table 3). Four of the sixteen genes were classic AhR responsive genes and exhibited statistically significant increases in expression with increasing dose of PCB126. These genes included Cyp1a1 (cytochrome P450 1A1), Cyp1b1 (cytochrome P450 1B1), Ugt1a6 (UDP glycosyltransferase 1 family, polypeptide A6) and Ugt1a7 (UDP glycosyltransferase 1 family, polypeptide A7) (Table 3). The remaining genes in Table 3 represent a novel set of sensitive genomic biomarkers for chronic exposure to PCB126.

\section{Identifying Genomic Biomarkers of Subchronic and Chronic Exposure to TCDD, PCB126 and PCB153}

During the 2-year cancer bioassays conducted by the NTP, it was observed that continuous exposure to DLCs beyond 30 weeks was necessary to lead to the formation of hepatic neoplastic lesions (Table 1). Rats treated with TCDD or PCB126 for 30 weeks, and then with vehicle control for the remainder of the two-year cancer bioassay showed no difference in the incidence of hepatocellular adenoma or cholangiocarcinoma when compared to control animals $[4,5]$. This suggests that persistent AhR activation with long-term alterations in gene expression are necessary for the development of hepatic neoplasia.

To identify genomic responses which are sustained throughout chronic exposure, comparative analysis of time-course microarray data was conducted. Subchronic (13 weeks) and chronic (52 weeks) exposure to TCDD (100 ng/kg/day), led to the differential expression of 103 and 299 genes, respectively (Table 2 and additional files 5 and 6). Through comparative analysis of subchronic and chronic exposure, 75 genes were identified that exhibited the same differential expression pattern at both time points (Figures 1 and 2). Following a similar paradigm for exposure to PCB126 (1000 ng/kg/day), 70 genes were identified that sustained the same differential expression pattern at both time points (Figures 1 and 2 and additional files 4 and 7). The non-hepatotoxic PCB153 (Table 1) caused the sustained differential expression of only 9 genes following subchronic and chronic exposure (Figures 1 and 2 and additional files 8 and 9). The sustained genomic responses to TCDD, PCB126 and PCB153 serve as genomic biomarkers of subchronic and chronic exposure to these compounds.

\section{Identification of Genomic Biomarkers of Exposure to AhR Ligands}

The hepatic gene expression signatures of TCDD and PCB126, while not identical, did exhibit a great deal of overlap. Genes that are shared by both expression signatures represent genomic biomarkers of subchronic and 
Table 2 Summary of differentially expressed genes in the livers of female Sprague-Dawley rats following p.o. exposure to TCDD, PCB126 and PCB153 for 13 and 52 weeks

\begin{tabular}{ll}
\hline $\mathbf{1 3}$ Week Subchronic Exposure Experiment & \\
\hline Exposure Group & Number of Differentially Expressed Genes \\
\hline $100 \mathrm{ng} / \mathrm{kg} /$ day TCDD & $103(18)$ \\
$1000 \mathrm{ng} / \mathrm{kg} /$ day PCB126 & $371(164)$ \\
$1000 \mu \mathrm{gg} / \mathrm{kg} /$ day PCB153 & $39(0)$ \\
\hline 52 Week Chronic Exposure Experiment & \\
\hline Exposure Group & Number of Differentially Expressed Genes \\
\hline $100 \mathrm{ng} / \mathrm{kg} /$ day TCDD & $299(22)$ \\
$30 \mathrm{ng} / \mathrm{kg} /$ day PCB126 & $52(1)$ \\
$300 \mathrm{ng} / \mathrm{kg} /$ day PCB126 & $128(15)$ \\
$1000 \mathrm{ng} / \mathrm{kg} /$ day PCB126 & $216(171)$ \\
$1000 \mathrm{mg} / \mathrm{kg} /$ day PCB153 & $47(1)$ \\
\hline
\end{tabular}

Shown are the total number of probe sets exhibiting a $\geq 2$-fold change in expression and a p-value $<0.05$ following the specified treatments. In parenthesis are probe sets that are still significant following Benjamini-Hochberg false discovery rate correction.

chronic exposure to two AhR ligands at toxic equivalent doses. Forty-one genomic biomarkers were identified that were shared by the expression signatures of TCDD and PCB126, but not PCB153 (Table 4 and Figure 3). These 41 genes are genomic biomarkers of exposure to two different AhR ligands and may be applicable to other AhR ligands as biomarkers of exposure (Table 4). Only one gene, Psat1 (phosphoserine aminotransferase 1 ), was found to be shared by the expression signatures of all three compounds (Figures 2 and 3), where its expression was up-regulated 3- to 8-fold following exposure to TCDD, PCB126, and PCB153.
The sustained differential expression of these $41 \mathrm{AhR}$ genomic biomarkers at both subchronic and chronic time-points suggests that these genomic responses are time-independent. To validate these biomarkers and determine if the differential expression of these genomic biomarkers are time-independent, real-time qPCR was utilized to evaluate hepatic gene expression in female $\mathrm{SD}$ rats at $24 \mathrm{~h}$ post-exposure to an acute dose of TCDD (5 $\mu \mathrm{g} / \mathrm{kg}$, po.) (Table 4). Thirty of these 41 genes exhibited a 2 -fold or greater change in expression $24 \mathrm{~h}$ post-exposure to TCDD $(5 \mu \mathrm{g} / \mathrm{kg})$. While acute exposure to TCDD resulted in less than a 2 -fold change in

Table 3 Relative fold change in $\mathbf{1 6}$ genes differentially expressed in livers of female Sprague-Dawley rats following 52 weeks of chronic p.o. exposure to $30 \mathrm{ng}, 300 \mathrm{ng}$ and $1000 \mathrm{ng} / \mathrm{kg} / \mathrm{day}$ РСB126

\begin{tabular}{|c|c|c|c|c|c|}
\hline \multirow[b]{2}{*}{ Transcript ID } & \multirow[b]{2}{*}{ Gene Symbol } & \multirow[b]{2}{*}{ Gene Name } & \multicolumn{3}{|c|}{ PCB126 dose $(\mathrm{ng} / \mathrm{kg} / \mathrm{d})$} \\
\hline & & & 30 & 300 & 1000 \\
\hline NM_012540 & Cyp1a1 $^{a}$ & Cytochrome P450, family 1 , subfamily a, polypeptide 1 & $499^{*}$ & $1263^{*}$ & $1551^{*}$ \\
\hline NM_012940 & Cyp $1 b 1^{a}$ & Cytochrome P450, family 1 , subfamily b, polypeptide 1 & 18 & $866^{*}$ & $2091^{*}$ \\
\hline NM_173339 & Ceacam $10^{\text {b }}$ & CEA-related cell adhesion molecule 10 & 17 & $660^{*}$ & $976^{*}$ \\
\hline NM_031530 & $\mathrm{Ccl} 2$ & Chemokine (C-C motif) ligand 2 & 5 & 11 & $31^{*}$ \\
\hline NM_001039691///NM_057105 & Ugt1a $6^{a}$ & UDP glycosyltransferase 1 family, polypeptide A6 & 3 & $11^{*}$ & $16^{*}$ \\
\hline NM_130407 & Ugt1a $7^{a}$ & UDP glycosyltransferase 1 family, polypeptide A7 & 3 & $23^{*}$ & $40^{*}$ \\
\hline NM_017127 & Chka & Choline kinase alpha & 2 & $7^{*}$ & $6^{*}$ \\
\hline NM_012656 & Sparc & Secreted acidic cysteine rich glycoprotein & 2 & 2 & $4^{*}$ \\
\hline $\begin{array}{l}\text { NM_031569///NM_057098/// } \\
\text { XM_001055907///XM_345486 }\end{array}$ & Oprl1///Tcea2 & Opioid receptor-like $1 / / /$ Transcription elongation factor A (SII), 2 & 2 & 4 & $4^{*}$ \\
\hline NM_024127 & Gadd45a & Growth arrest and DNA-damage-inducible 45 alpha & 2 & 4 & $4^{*}$ \\
\hline NM_012600 & Me1 & Malic enzyme 1 & 2 & $2^{*}$ & $4^{*}$ \\
\hline NM_001037979 & Adipor $^{\mathrm{b}}$ & Adiponectin receptor 2 & -3 & -2 & $-6^{*}$ \\
\hline NM_012672 & Thrb & Thyroid hormone receptor beta & -3 & -3 & $-3^{*}$ \\
\hline NM_032071 & Synj2 & Synaptojanin 2 & -3 & -3 & $-4^{*}$ \\
\hline XM_001071608///XM_213849 & Nfix & Nuclear factor $\mathrm{I} / \mathrm{X}$ & -3 & -3 & $-5^{*}$ \\
\hline NM_012988 & Nfia & Nuclear factor I/A & -4 & -4 & $-3^{*}$ \\
\hline
\end{tabular}

${ }^{a}$ Statistically different ( $p$-value $=0.05$ ) between doses using ANOVA with Tukey post-hoc test; ${ }^{\mathrm{b}}$ Statistically different between 300 ng and 1000 ng doses only; * Genes with p-value < 0.05 following Benjamini-Hochberg FDR correction. 


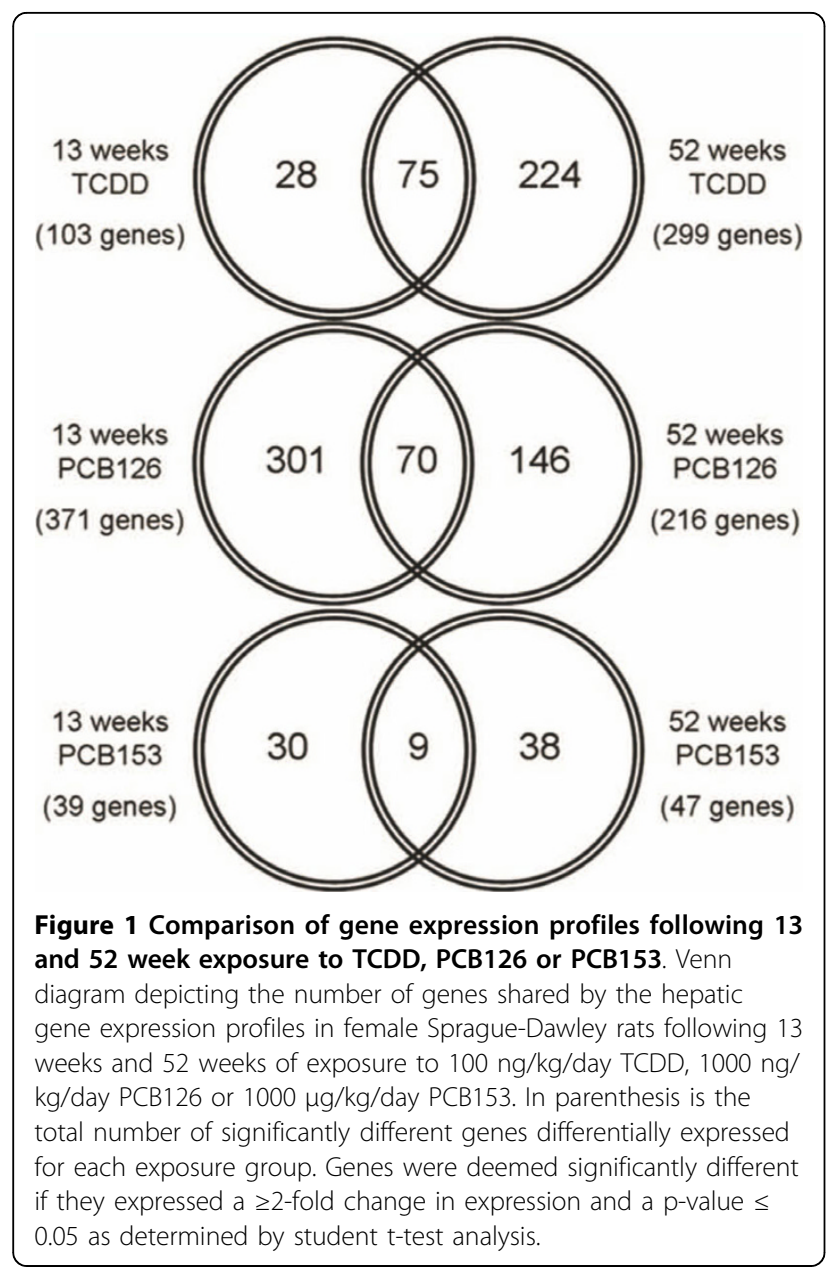

the hepatic expression of 10 AhR genomic biomarkers, 9 of the 10 genes exhibited a similar trend in the up or down regulation observed following subchronic and chronic exposure to TCDD and PCB126 (Table 4). The 30 genes confirmed through real-time qPCR to be upor down-regulated ( $\geq 2$-fold change in expression) represent time-independent genomic biomarkers of AhR ligands that are responsive at acute, subchronic and chronic time-points and may be applied as a diagnostic and mechanistic tool for the evaluation of AhR-ligand like activity in the female SD rat model.

The 41 AhR genomic biomarkers were analyzed for the presence of putative DRE sites (5'-GCGTG-3') within 5000 bp above and 1000 bp below the transcriptional start site. The gene regulatory sequences were obtained for 39 of the 41 genes. Sequences for Alas1 (aminolevulinate, delta-, synthase 1) and Mtmr7 (myotubularin related protein 7 ) were not available through the UCSC genome bioinformatic database and thus prevented analysis for DRE sites. Of the 39 genes assessed, 25 of the genes contained one or more putative DRE site (Table 4). This included genes which have been previously shown to be regulated by AhR ligands including the cytochrome $\mathrm{P} 450$ genes Cyp 1a1 and Cyp1b1 [10] the UDP glycotransferase genes Ugt1a6 and Ugt1a7 [27], Hal (histidine ammonia lyase) [28], Nqo1 (NAD(P)H dehydrogenase, quinone 1) [14], Srd5a1 (steroid-5-alpha-reductase, alpha polypeptide) [29] and Tsc22d1 (TSC22 domain family, member 1; also known as Tgfb1i4) [30].

\section{Phenotypic Anchoring of 52-week Hepatic Gene Expression to Hepatocellular Adenoma and Cholangiocarcinoma}

Following chronic exposure to TCDD and PCB126 a significant increase in the incidence of HCA and cholangiocarcinoma $(\mathrm{CC})$ is observed in the livers of female SD rats (Table 1). The appearance of $\mathrm{HCA}$ and $\mathrm{CC}$ was observed with 104 weeks of exposure to TCDD and PCB126, but not at earlier time points or with PCB153. To relate genomic responses to the observed liver pathology, comparative analysis was conducted between the 52 week hepatic gene expression profiles of TCDD, PCB126 and PCB153, and gene array data from published studies on human ICC [24], human HCA [23] and rat $\mathrm{HCA}[22]$.

Human ICC gene expression profiles were obtained from microarray studies conducted on 13 [25] and 25 [24] microdissected cholangiocarcinomas. Between the two studies, 24 genes were identified as exhibiting the same differential expression pattern in human ICC and in rat liver following 52 weeks of chronic exposure to TCDD and/or PCB126, but not PCB153 (Table 5). Among these genes, 4 were unique to the Obama et al. (2005) ICC expression profile, 18 were unique to the Miller et al. (2009) ICC expression profile and 2 genes were shared between the two ICC expression profiles. The two genes that were present in both ICC expression profiles were Gata6 (GATA binding protein 6) and Timp3 (tissue inhibitor of metalloproteinase 3).

Human and Sprague-Dawley rat HCA gene expression profiles obtained from microdissected HCA tissues [22] were used for comparative analysis. Additional rat HCA gene expression profiles were kindly provided by Dr. Sun Hee Yim (National Cancer Institute, Bethesda, MD). Seventeen genes were identified which exhibited the same differential expression pattern in human HCA as that seen in the livers of rats exposed for 52 weeks to TCDD and/or PCB126 (Table 6). Additionally, seven genes were identified which exhibited the same differential expression pattern in both rat HCA gene expression studies and in livers from rats exposed for 52 weeks to TCDD and/or PCB126, but not PCB153 (Table 6). Interestingly, the genes Gata6, Agt (angiotensinogen (serpin peptidase inhibitor, clade A, member 8)) and Bhlhb2 (basic helix-loop-helix domain containing, class B2) 


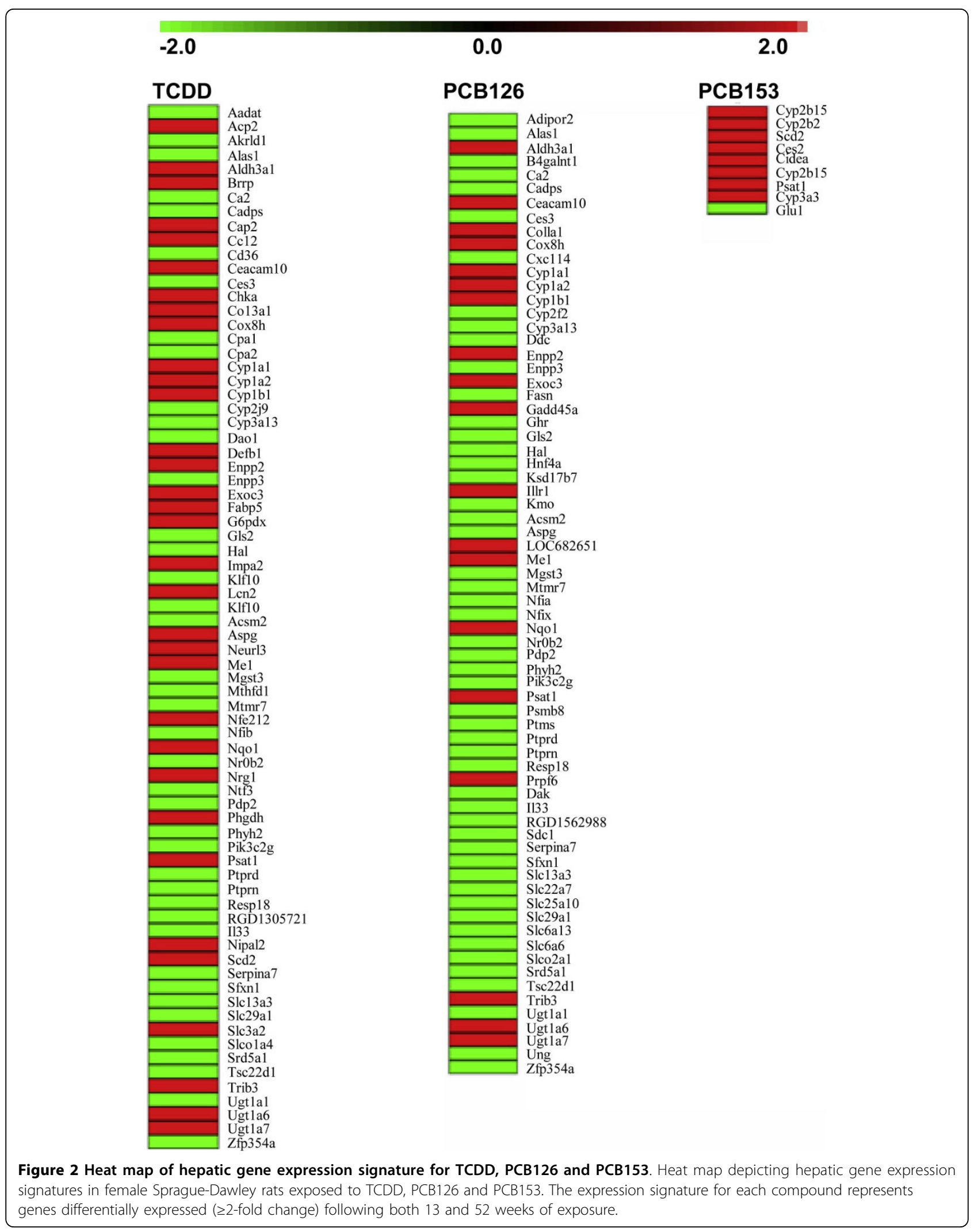


Table 4 Relative fold change in genes differentially expressed in livers of female Sprague-Dawley rats following 13 weeks and 52 weeks of p.o. exposure to $1000 \mathrm{ng} / \mathrm{kg} / \mathrm{day}$ PCB126 and $100 \mathrm{ng} / \mathrm{kg} / \mathrm{day}$ TCDD, and $24 \mathrm{~h}$ post-exposure to $5 \mu \mathrm{g} / \mathrm{kg}$ TCDD, p.o

\begin{tabular}{|c|c|c|c|c|c|c|c|c|}
\hline $\begin{array}{l}\text { Gene } \\
\text { Symbol }\end{array}$ & Gene Name & $\begin{array}{l}13 \text { wk } \\
\text { PCB126 }\end{array}$ & $\begin{array}{l}13 \mathbf{w k} \\
\mathrm{TCDD}^{\mathrm{a}}\end{array}$ & $\begin{array}{l}52 \text { wk } \\
\text { PCB126 }\end{array}$ & $\begin{array}{l}52 \mathrm{wk} \\
\mathrm{TCDD}^{\mathrm{a}}\end{array}$ & $\begin{array}{l}24 \mathrm{~h} \\
\text { TCDD }^{\mathrm{b}}\end{array}$ & $\begin{array}{l}\text { DRE site } \\
\text { in Rat }^{c}\end{array}$ & $\begin{array}{l}\text { DRE site in } \\
\text { Human }^{c}\end{array}$ \\
\hline Cyp1a1 & Cytochrome P450, family 1, subfamily a, polypeptide 1 & $1140^{*}$ & $1026^{*}$ & $1551^{*}$ & $1277^{*}$ & $127881^{* *}$ & YES (8) & YES (11) \\
\hline Cyp1b1 & Cytochrome P450, family 1 , subfamily b, polypeptide 1 & $519^{*}$ & $743^{*}$ & $2091^{*}$ & $1288^{*}$ & $121^{\mathrm{d} * *}$ & YES (9) & YES (7) \\
\hline Ceacam10 & CEA-related cell adhesion molecule 10 & $369^{*}$ & $620^{*}$ & $976^{*}$ & $973^{*}$ & $8.5^{* *}$ & NO & $\mathrm{N} / \mathrm{P}$ \\
\hline Cox8h & Cytochrome c oxidase subunit VIII-H (heart/muscle) & $66^{*}$ & $312^{*}$ & $24^{*}$ & $27^{*}$ & N/D & NO & N/A \\
\hline Nqo1 & $\mathrm{NAD}(\mathrm{P}) \mathrm{H}$ dehydrogenase, quinone 1 & $21^{*}$ & 20 & $9^{*}$ & $8^{*}$ & $37.0^{* *}$ & YES (7) & YES (2) \\
\hline Ugt1a7 & UDP glycosyltransferase 1 family, polypeptide A7 & $14^{*}$ & $85^{*}$ & $40^{*}$ & $33^{*}$ & $24.5^{* *}$ & YES (4) & YES (2) \\
\hline Ugt1a6 & UDP glycosyltransferase 1 family, polypeptide A6 & $11^{*}$ & $56^{*}$ & $16^{*}$ & $12^{*}$ & $383.6^{* *}$ & YES (6) & YES (2) \\
\hline Cyp1a2 & Cytochrome P450, family 1 , subfamily a, polypeptide 2 & $7^{*}$ & $3^{*}$ & $2^{*}$ & 2 & $38.5^{* *}$ & NO & YES (3) \\
\hline Enpp2 & Ectonucleotide pyrophosphatase/phosphodiesterase 2 & $6^{*}$ & $6^{*}$ & $5^{*}$ & 4 & $2.6^{* *}$ & YES (1) & NO \\
\hline Exoc3 & Exocyst complex component 3 & $6^{*}$ & $32^{*}$ & $21^{*}$ & $23^{*}$ & $8.1^{* *}$ & NO & YES (7) \\
\hline Aldh3a1 & Aldehyde dehydrogenase family 3 , member $A 1$ & $5^{*}$ & $57^{*}$ & $1493^{*}$ & $1156^{*}$ & $10.2^{* *}$ & YES (2) & YES (5) \\
\hline Me1 & Malic enzyme 1 & $4^{*}$ & 3 & $4^{*}$ & 3 & $2.4^{* *}$ & YES (2) & YES (2) \\
\hline Trib3 & Tribbles homolog 3 (Drosophila) & $2^{*}$ & $8^{*}$ & $13^{*}$ & 16 & $2.2^{* *}$ & YES (1) & YES (3) \\
\hline Tsc22d1 & TSC22 domain family, member 1 & -2 & -2 & $-6^{*}$ & -4 & 1.5 & YES (4) & YES (2) \\
\hline Gls2 & Glutaminase 2 (liver, mitochondrial) & $-2^{*}$ & -3 & $-6^{*}$ & -4 & $-2.5^{* *}$ & YES (2) & YES (3) \\
\hline Zfp354a & Zinc finger protein $354 \mathrm{~A}$ & -2 & -2 & $-8^{*}$ & -5 & -5.3 & YES (1) & YES (1) \\
\hline Alas1 & Aminolevulinic acid synthase 1 & $-2^{*}$ & -2 & -3 & -3 & -1.6 & N/A & YES (2) \\
\hline Phyh2 & Phytanoyl-CoA 2-hydroxylase 2 & -2 & -4 & $-3^{*}$ & -3 & -1.6 & YES (1) & YES (1) \\
\hline Ca2 & Carbonic anhydrase 2 & -3 & $-8^{*}$ & $-6^{*}$ & -3 & $-1.9^{d}$ & NO & YES (4) \\
\hline Sfxn1 & Sideroflexin 1 & $-3^{*}$ & $-3^{*}$ & $-3^{*}$ & -2 & -2.9 & NO & YES (2) \\
\hline Mtmr7 & Myotubularin related protein 7 & $-3^{*}$ & -3 & $-5^{*}$ & -5 & $-3.0^{* *}$ & N/A & YES (2) \\
\hline Pik3c2g & $\begin{array}{l}\text { Phosphatidylinositol 3-kinase, C2 domain containing, } \\
\text { gamma polypeptide }\end{array}$ & -3 & -2 & $-3^{*}$ & -3 & -1.5 & NO & NO \\
\hline Acsm2 & Acyl-CoA synthetase medium-chain family member 2 & -3 & -26 & $-12^{*}$ & -14 & -3.9 & YES (2) & N/P \\
\hline Slc29a1 & $\begin{array}{l}\text { Solute carrier family } 29 \text { (nucleoside transporters), } \\
\text { member } 1\end{array}$ & $-3^{*}$ & -3 & $-3^{*}$ & $-2^{*}$ & -2.1 & YES (2) & YES (1) \\
\hline Cadps & Ca2+-dependent secretion activator & -3 & -3 & -3 & -3 & $-2.6^{* *}$ & YES (1) & YES (5) \\
\hline $\mathrm{Hal}$ & Histidine ammonia lyase & -3 & -2 & $-17^{*}$ & -10 & -1.3 & YES (2) & NO \\
\hline Сур3а13 & Cytochrome P450, family 3, subfamily a, polypeptide 13 & -3 & $-139^{*}$ & $-610^{*}$ & $-606^{*}$ & $-5.6^{\mathrm{d} * *}$ & NO & $N / P$ \\
\hline Ptprd & Protein tyrosine phosphatase, receptor type, D & $-3^{*}$ & -2 & -3 & -2 & -1.9 & YES (4) & YES (2) \\
\hline Ces3 & Carboxylesterase 3 & $-3^{*}$ & -9 & $-9^{*}$ & -6 & $-2.8^{\mathrm{d}}$ & NO & YES (2) \\
\hline Mgst3 & Microsomal glutathione S-transferase 3 & -3 & -3 & $-4^{*}$ & -4 & $-3.4^{* *}$ & YES (7) & YES (4) \\
\hline Serpina7 & $\begin{array}{l}\text { Serine (or cysteine) peptidase inhibitor, clade A (alpha-1 } \\
\text { antipeptidase, antitrypsin), member } 7\end{array}$ & -3 & -15 & $-21^{*}$ & -16 & $-3.3^{d}$ & NO & NO \\
\hline NrOb2 & Nuclear receptor subfamily 0, group B, member 2 & $-3^{*}$ & -2 & $-3^{*}$ & -2 & $-6.4^{* *}$ & NO & YES (2) \\
\hline Aspg & Asparaginase homolog (S. cerevisiae) & $-4^{*}$ & -10 & $-41^{*}$ & -28 & $-4.1^{* *}$ & YES (8) & $\mathrm{N} / \mathrm{P}$ \\
\hline 1133 & II33 interleukin 33 & $-4^{*}$ & -3 & $-3^{*}$ & -3 & $-2.1^{* *}$ & NO & $\mathrm{N} / \mathrm{P}$ \\
\hline Ptprn & Protein tyrosine phosphatase, receptor type, $\mathrm{N}$ & -4 & -3 & $-4^{*}$ & -3 & -1 & YES (2) & YES (1) \\
\hline Srd5a1 & Steroid 5 alpha-reductase 1 & -4 & -6 & $-14^{*}$ & -11 & $-2.0^{\mathrm{d} * *}$ & YES (1) & YES (8) \\
\hline Enpp3 & Ectonucleotide pyrophosphatase/phosphodiesterase 3 & $-4^{*}$ & $-4^{*}$ & $-5^{*}$ & -4 & $-2.3^{* *}$ & NO & NO \\
\hline Pdp2 & Pyruvate dehydrogenase phosphatase isoenzyme 2 & -4 & -3 & $-9^{*}$ & -3 & -1.8 & YES (1) & YES (3) \\
\hline Ugt1a1 & UDP glycosyltransferase 1 family, polypeptide A1 & $-5^{*}$ & -3 & $-3^{*}$ & -3 & -1.3 & YES (4) & YES (4) \\
\hline Slc13a3 & $\begin{array}{l}\text { Solute carrier family } 13 \text { (sodium-dependent } \\
\text { dicarboxylate transporter), member } 3\end{array}$ & -5 & -7 & $-4^{*}$ & -5 & $-3.3^{d * *}$ & YES (3) & YES (1) \\
\hline Resp18 & Regulated endocrine-specific protein 18 & -7 & -6 & $-15^{*}$ & -34 & $-5.7^{* *}$ & NO & N/A \\
\hline
\end{tabular}

Shown are genes for which expression from microarray analysis significantly differed ( $\mathrm{p}<0.05$ as determined by the student t-test), by at least 2 -fold, compared to the control group. ${ }^{a}$ Fold changes in hepatic gene expression from microarray analysis; ${ }^{b}$ Fold changes in hepatic gene expression from qPCR at $24 \mathrm{~h}$ postexposure to TCDD; ${ }^{c}$ DREs identified in genomic DNA sequences spanning 5000 bp above and 1000 bp below the transcriptional start site. The number in parenthesis indicates the number of DREs present; ${ }^{d}$ Values from Ovando et al. 2006; *Genes with p-value < 0.05 following Benjamini-Hochberg FDR correction; ${ }^{* *}$ Statistically different $(P \leq 0.05)$ between control and treated animals $(n=3)$ for qPCR; N/P - Gene not present in human genome; N/D - Gene expression could not be evaluated for that treatment; N/A - Not available in the UCSC genome bioinformatics database. 


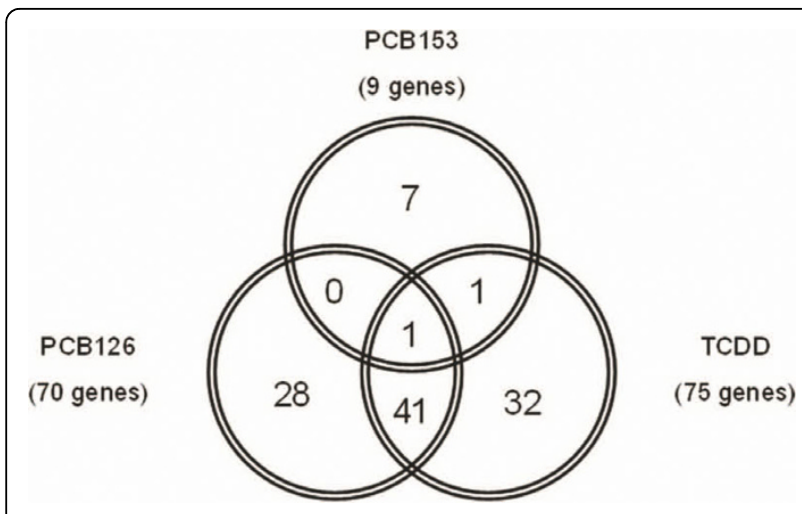

Figure 3 Comparison of hepatic gene expression signatures for TCDD, PCB126 and PCB153. Venn diagram depicting the number of genes shared by the hepatic gene expressions signatures in female Sprague-Dawley rats following subchronic and chronic exposure to TCDD (100 ng/kg/day), PCB126 (1000 ng/kg/day) or PCB153 $(1000 \mu \mathrm{g} / \mathrm{kg} /$ day). In parenthesis is the total number of genes differentially expressed for each compound following both 13 and 52 weeks of exposure. The 41 genes shared in common by exposures to TCDD and PCB126 represent genomic biomarkers of subchronic and chronic exposure to AhR ligands or the time independent gene expression signature of the AhR ligands.

were down-regulated in ICC and HCA as well as the 52 week expression profiles of TCDD and/or PCB126, but not PCB153.

\section{Discussion}

Toxicological studies conducted by the National Toxicology Program have shown a significant increase in the incidence of hepatic neoplastic and non-neoplastic lesions in female SD rats following chronic exposure to TCDD and PCB126 [4,5,7]. Studies with AhR knockout mice have shown that the acute toxicity of TCDD is dependent on the functionality of the AhR $[11,12]$. This suggests that the hepatotoxic effects of TCDD and related dioxin-like compounds (DLCs) are mediated through the AhR, and changes in gene expression resulting from activation of this transcription factor are likely the principle mode of toxicity of these compounds. In an effort to identify the genomic responses that may be contributing to the observed liver toxicity, toxicogenomics was conducted to provide a comprehensive description of hepatic gene expression with acute exposure to TCDD and subchronic and chronic exposure to TCDD and PCB126, the most potent dioxin-like PCB.

Through the comparative analysis of time-course microarray data, hepatic gene expression signatures of subchronic and chronic exposure to TCDD, PCB126 and PCB153 were identified (Figures 1 \&2). The hepatic gene expression signature of PCB126 (1000 ng/kg/day) consists of 70 genes which show sustained differential expression at both subchronic (13 weeks) and chronic (52 weeks) time points (Figure 1). In addition, a dose response analysis of hepatic gene expression was conducted following 52 weeks of chronic exposure to $30 \mathrm{ng}$, $300 \mathrm{ng}$ and $1000 \mathrm{ng} / \mathrm{kg} /$ day PCB126. Gene array analysis showed a positive correlation between PCB126 dose and the number of genes differentially expressed (Table 2). A similar dose response relationship has been reported for female mice subjected to an acute exposure to PCB126 [31]. Comparative analysis of the hepatic expression profiles of chronic (52 weeks) exposure to 30 ng, $300 \mathrm{ng}$ and $1000 \mathrm{ng} / \mathrm{kg} /$ day PCB126 identified 16 genes which were differentially expressed at all three concentrations (Table 3). Interestingly, of those 16 genes, Ccl2 (chemokine (C-C motif) ligand 2), Chka (choline kinase alpha), Thrb (thyroid hormone receptor beta) and Synj2 (synaptojanin 2) are not present in the 13- and 52 week hepatic gene expression signature of PCB126 (Figure 2). This indicates that even though differential expression of Ccl2, Chka, Thrb and Synj2 are sensitive endpoints of chronic PCB126 exposure, as evident in their responsiveness at $30 \mathrm{ng} / \mathrm{kg} /$ day PCB126, these changes do not manifest themselves following 13 weeks of subchronic exposure to $1000 \mathrm{ng} / \mathrm{kg} /$ day PCB126. These four genes help illustrate the caution that one must use in categorizing a gene as a biomarker of exposure. As seen in these results, Ccl2, Chka, Thrb and Synj2 are examples of sensitive genomic responses to chronic PCB126 exposure, however, they do not exhibit the early subchronic responsiveness that would make them beneficial as biomarkers in early stage identification of PCB126 exposure.

Pathological data shows that continuous exposure to TCDD and PCB126 beyond a period of 13 weeks is necessary to cause the formation of hepatic neoplastic and non-neoplastic lesions [4,5]. Considering the relevance of genomic responses to the toxicity of DLCs, these data suggest that changes in gene expression that are sustained throughout chronic treatment are playing a pivotal role in the development of hepatic lesions. Seventy-five and 70 genes were identified which showed sustained differential expression following subchronic (13 weeks) and chronic (52 weeks) exposure to TCDD and PCB126, respectively (Figures 1 and 2). The sustained differential expression of these genes over a 52 week span suggests that these genes are likely playing an important role in the hepatotoxic effects of TCDD and PCB126. Nine genes showed sustained differential expression following subchronic and chronic exposure to PCB153 (Figures 1 and 2). Only one gene, Psat1, was differentially expressed (up-regulated 3- to 8-fold) in the expression signatures of PCB153, TCDD and PCB126 (Figure 3). Psat1 is a phosphoserine aminotransferase involved in serine biosynthesis whose expression has 
Table 5 Relative fold change in genes differentially expressed in human intrahepatic cholangiocarcinoma (ICC) and the hepatic gene expression profiles of rats exposed to TCDD, PCB126, and PCB153 p.o. for 52 weeks

\begin{tabular}{|c|c|c|c|c|c|c|c|c|}
\hline Transcript ID & $\begin{array}{l}\text { Rat } \\
\text { Ortholog }\end{array}$ & Rat Gene Name & $\begin{array}{l}\text { Human } \\
\text { Ortholog }\end{array}$ & $\begin{array}{l}\text { ICC } \\
{[25]}\end{array}$ & $\begin{array}{l}\text { ICC } \\
{[24]}\end{array}$ & $\begin{array}{l}\text { TCDD } \\
100 \mathrm{ng} / \mathrm{kg} / \text { day }\end{array}$ & $\begin{array}{l}\text { PCB126 } \\
1000 \mathrm{ng} / \mathrm{kg} / \text { day }\end{array}$ & $\begin{array}{l}\text { PCB153 } \\
1000 \mu \mathrm{g} / \mathrm{kg} / \text { day }\end{array}$ \\
\hline NM_144755 & Trib3 & $\begin{array}{l}\text { Tribbles homolog } 3 \\
\text { (Drosophila) }\end{array}$ & TRIB3 & 18 & $\mathrm{~N} / \mathrm{C}$ & 16 & 13 & $\mathrm{~N} / \mathrm{C}$ \\
\hline NM_016988 & Acp2 & $\begin{array}{l}\text { Acid phosphatase } 2, \\
\text { lysosomal }\end{array}$ & ACP2 & 2 & $\mathrm{~N} / \mathrm{C}$ & 3 & 2 & $\mathrm{~N} / \mathrm{C}$ \\
\hline NM_021261 & Tmsb10 & Thymosin, beta 10 & TMSB10 & 2 & $\mathrm{~N} / \mathrm{C}$ & 2 & $\mathrm{~N} / \mathrm{C}$ & $\mathrm{N} / \mathrm{C}$ \\
\hline NM_017059 & Bax & $\begin{array}{l}\text { Bcl2-associated X } \\
\text { protein }\end{array}$ & BAX & 4 & $\mathrm{~N} / \mathrm{C}$ & 2 & $\mathrm{~N} / \mathrm{C}$ & $\mathrm{N} / \mathrm{C}$ \\
\hline NM_019287 & Apob & Apolipoprotein B & $\mathrm{APOB}$ & $\mathrm{N} / \mathrm{C}$ & -3 & -9 & $\mathrm{~N} / \mathrm{C}$ & $\mathrm{N} / \mathrm{C}$ \\
\hline NM_019185 & Gata6 & GATA binding protein 6 & GATA6 & -4 & -5 & -3 & -4 & $\mathrm{~N} / \mathrm{C}$ \\
\hline NM_013219 & Cadps & $\begin{array}{l}\text { Ca2+-dependent } \\
\text { secretion activator }\end{array}$ & CADPS & $\mathrm{N} / \mathrm{C}$ & -16 & -3 & -3 & $\mathrm{~N} / \mathrm{C}$ \\
\hline NM_012886 & Timp3 & $\begin{array}{l}\text { Tissue inhibitor of } \\
\text { metalloproteinase } 3 \\
\text { (Sorsby fundus } \\
\text { dystrophy, } \\
\text { pseudoinflammatory) }\end{array}$ & TIMP3 & -11 & -3 & -2 & $\mathrm{~N} / \mathrm{C}$ & $\mathrm{N} / \mathrm{C}$ \\
\hline NM_017158 & Cyp2c7 & $\begin{array}{l}\text { Cytochrome P450, } \\
\text { family 2, subfamily c, } \\
\text { polypeptide } 7\end{array}$ & CYP2C9 & $\mathrm{N} / \mathrm{C}$ & -3 & -2 & -2 & $\mathrm{~N} / \mathrm{C}$ \\
\hline NM_134432 & Agt & $\begin{array}{l}\text { Angiotensinogen } \\
\text { (serpin peptidase } \\
\text { inhibitor, clade A, } \\
\text { member 8) }\end{array}$ & AGT & $\mathrm{N} / \mathrm{C}$ & -6 & -2 & $\mathrm{~N} / \mathrm{C}$ & $\mathrm{N} / \mathrm{C}$ \\
\hline NM_053598 & Nudt4 & $\begin{array}{l}\text { Nudix (nucleoside } \\
\text { diphosphate linked } \\
\text { moiety X)-type motif } 4\end{array}$ & NUDT4 & -3 & $\mathrm{~N} / \mathrm{C}$ & -2 & $\mathrm{~N} / \mathrm{C}$ & $\mathrm{N} / \mathrm{C}$ \\
\hline NM_013029 & St8sia3 & $\begin{array}{l}\text { ST8 alpha-N-acetyl- } \\
\text { neuraminide alpha-2,8- } \\
\text { sialyltransferase } 3\end{array}$ & ST8SIA3 & -2 & $\mathrm{~N} / \mathrm{C}$ & -2 & $\mathrm{~N} / \mathrm{C}$ & $\mathrm{N} / \mathrm{C}$ \\
\hline NM_012596 & Lepr & Leptin receptor & LEPR & -8 & $\mathrm{~N} / \mathrm{C}$ & -2 & $\mathrm{~N} / \mathrm{C}$ & $\mathrm{N} / \mathrm{C}$ \\
\hline NM_022501 & Crip2 & Cysteine-rich protein 2 & CRIP & -9 & $\mathrm{~N} / \mathrm{C}$ & -3 & -3 & $\mathrm{~N} / \mathrm{C}$ \\
\hline NM_031132 & Tgfbr2 & $\begin{array}{l}\text { Transforming growth } \\
\text { factor, beta receptor II }\end{array}$ & TGFBR2 & -4 & $N / C$ & -3 & $\mathrm{~N} / \mathrm{C}$ & $\mathrm{N} / \mathrm{C}$ \\
\hline NM_001025271 & Sfpq & $\begin{array}{l}\text { Splicing factor proline/ } \\
\text { glutamine rich } \\
\text { (polypyrimidine tract } \\
\text { binding protein } \\
\text { associated) }\end{array}$ & SFPQ & -5 & $N / C$ & -3 & $\mathrm{~N} / \mathrm{C}$ & $\mathrm{N} / \mathrm{C}$ \\
\hline NM_001007235 & Itpr1 & $\begin{array}{l}\text { Inositol 1,4,5- } \\
\text { triphosphate receptor } 1\end{array}$ & ITPR1 & -3 & $\mathrm{~N} / \mathrm{C}$ & -3 & -3 & $\mathrm{~N} / \mathrm{C}$ \\
\hline NM_053328 & Bhlhb2 & $\begin{array}{l}\text { Basic helix-loop-helix } \\
\text { domain containing, } \\
\text { class B2 }\end{array}$ & BHLHB2 & -4 & $\mathrm{~N} / \mathrm{C}$ & -4 & $\mathrm{~N} / \mathrm{C}$ & $\mathrm{N} / \mathrm{C}$ \\
\hline NM_001013137 & Cxcl14 & $\begin{array}{l}\text { Chemokine }(\mathrm{C}-\mathrm{X}-\mathrm{C} \\
\text { motif) ligand } 14\end{array}$ & CXCL14 & -11 & $\mathrm{~N} / \mathrm{C}$ & -4 & -10 & $\mathrm{~N} / \mathrm{C}$ \\
\hline NM_031561 & $\mathrm{Cd} 36$ & Cd36 antigen & CD36 & -5 & $N / C$ & -6 & -4 & $\mathrm{~N} / \mathrm{C}$ \\
\hline NM_031135 & Klf10 & Kruppel-like factor 10 & KLF10 & -4 & $\mathrm{~N} / \mathrm{C}$ & -10 & $\mathrm{~N} / \mathrm{C}$ & $\mathrm{N} / \mathrm{C}$ \\
\hline NM_022251 & Enpep & $\begin{array}{l}\text { Glutamyl } \\
\text { aminopeptidase }\end{array}$ & ENPEP & -2 & $\mathrm{~N} / \mathrm{C}$ & -12 & -5 & $\mathrm{~N} / \mathrm{C}$ \\
\hline NM_031648 & Fxyd1 & $\begin{array}{l}\text { FXYD domain- } \\
\text { containing ion } \\
\text { transport regulator } 1\end{array}$ & FXYD1 & -14 & $N / C$ & $\mathrm{~N} / \mathrm{C}$ & -2 & $\mathrm{~N} / \mathrm{C}$ \\
\hline NM_053698 & Cited2 & $\begin{array}{l}\text { Cbp/p300-interacting } \\
\text { transactivator, with Glu/ } \\
\text { Asp-rich carboxy- } \\
\text { terminal domain, } 2\end{array}$ & CITED2 & -4 & $N / C$ & $\mathrm{~N} / \mathrm{C}$ & -4 & $\mathrm{~N} / \mathrm{C}$ \\
\hline
\end{tabular}

$\mathrm{N} / \mathrm{C}$ indicates no change in gene expression for that treatment. 
Table 6 Relative fold change in genes differentially expressed in human hepatocellular adenoma (HCA), rat HCA and the hepatic gene expression profiles of rats exposed to TCDD, PCB126, and PCB153 p.o. for 52 weeks

\begin{tabular}{|c|c|c|c|c|c|c|c|c|}
\hline Transcript ID & $\begin{array}{l}\text { Gene } \\
\text { Symbol }\end{array}$ & Rat Gene Name & $\begin{array}{l}\text { Human } \\
\text { Ortholog }\end{array}$ & $\begin{array}{l}\text { HCA } \\
{[23]}\end{array}$ & $\begin{array}{l}\mathrm{HCA} \\
{[22]}\end{array}$ & $\begin{array}{l}\text { TCDD } \\
100 \mathrm{ng} / \\
\mathrm{kg} / \text { day }\end{array}$ & $\begin{array}{l}\text { PCB126 } \\
1000 \mathrm{ng} / \\
\mathrm{kg} / \text { day }\end{array}$ & $\begin{array}{l}\text { PCB153 } \\
1000 \mu \mathrm{g} / \\
\mathrm{kg} / \mathrm{day}\end{array}$ \\
\hline NM_053401 & Ngfrap1 & $\begin{array}{l}\text { Nerve growth factor receptor (TNFRSF16) associated } \\
\text { protein } 1\end{array}$ & NGFRAP1 & $\mathrm{N} / \mathrm{C}$ & 13 & 8 & 6 & $\mathrm{~N} / \mathrm{C}$ \\
\hline NM_012752 & $\mathrm{Cd} 24$ & CD24 antigen & CD24 & 10 & $\mathrm{~N} / \mathrm{C}$ & 7 & 4 & $\mathrm{~N} / \mathrm{C}$ \\
\hline NM_017127 & Chka & Choline kinase alpha & CHKA & 2 & $\mathrm{~N} / \mathrm{C}$ & 5 & 6 & $\mathrm{~N} / \mathrm{C}$ \\
\hline NM_057104 & Enpp2 & $\begin{array}{l}\text { Ectonucleotide pyrophosphatase/phosphodiesterase } \\
2\end{array}$ & ENPP2 & 4 & $\mathrm{~N} / \mathrm{C}$ & 4 & 5 & $\mathrm{~N} / \mathrm{C}$ \\
\hline NM_017166 & Stmn1 & Stathmin 1 & STMN1 & 2 & $\mathrm{~N} / \mathrm{C}$ & 4 & $\mathrm{~N} / \mathrm{C}$ & 2 \\
\hline NM_145878 & Fabp5 & Fatty acid binding protein 5 , epidermal & FABP5 & 2 & $\mathrm{~N} / \mathrm{C}$ & 4 & 3 & $\mathrm{~N} / \mathrm{C}$ \\
\hline NM_022298 & Tuba1 & Tubulin, alpha 1 & TUBA4A & $\mathrm{N} / \mathrm{C}$ & 11 & 3 & $\mathrm{~N} / \mathrm{C}$ & $\mathrm{N} / \mathrm{C}$ \\
\hline NM_053515 & Slc25a4 & $\begin{array}{l}\text { Solute carrier family } 25 \text { (mitochondrial carrier; } \\
\text { adenine nucleotide translocator), member } 4\end{array}$ & SLC25A4 & $\mathrm{N} / \mathrm{C}$ & 8 & 3 & N/C & $\mathrm{N} / \mathrm{C}$ \\
\hline NM_012862 & Mgp & Matrix Gla protein & MGP & 4 & $\mathrm{~N} / \mathrm{C}$ & 3 & 3 & $\mathrm{~N} / \mathrm{C}$ \\
\hline NM_012946 & Sparcl1 & SPARC-like 1 (mast9, hevin) & SPARCL1 & 3 & $\mathrm{~N} / \mathrm{C}$ & 2 & 2 & $\mathrm{~N} / \mathrm{C}$ \\
\hline NM_030987 & Gnb1 & Guanine nucleotide binding protein, beta 1 & GNB1 & 2 & $\mathrm{~N} / \mathrm{C}$ & $\mathrm{N} / \mathrm{C}$ & 3 & $\mathrm{~N} / \mathrm{C}$ \\
\hline NM_031795 & Ugcg & UDP-glucose ceramide glucosyltransferase & UGCG & 2 & $\mathrm{~N} / \mathrm{C}$ & $\mathrm{N} / \mathrm{C}$ & $\mathrm{N} / \mathrm{C}$ & 2 \\
\hline NM_023103 & Mug1 & Murinoglobulin 1 homolog (mouse) & none & $\mathrm{N} / \mathrm{C}$ & -5 & -2 & $\mathrm{~N} / \mathrm{C}$ & $\mathrm{N} / \mathrm{C}$ \\
\hline NM_134432 & Agt & $\begin{array}{l}\text { Angiotensinogen (serpin peptidase inhibitor, clade } \\
\text { A, member 8) }\end{array}$ & AGT & N/C & -5 & -2 & N/C & $\mathrm{N} / \mathrm{C}$ \\
\hline NM_012899 & Alad & Aminolevulinate, delta-, dehydratase & $A L A D$ & -2 & $\mathrm{~N} / \mathrm{C}$ & -2 & -3 & $\mathrm{~N} / \mathrm{C}$ \\
\hline NM_053770 & Argbp2 & Arg/Abl-interacting protein ArgBP2 & ARGBP2 & -3 & $\mathrm{~N} / \mathrm{C}$ & -2 & $\mathrm{~N} / \mathrm{C}$ & $\mathrm{N} / \mathrm{C}$ \\
\hline NM_022508 & Mthfd1 & $\begin{array}{l}\text { Methylenetetrahydrofolate dehydrogenase (NADP+ } \\
\text { dependent), methenyltetrahydrofolate } \\
\text { cyclohydrolase, formyltetrahydrofolate synthase }\end{array}$ & MTHFD1 & -5 & $\mathrm{~N} / \mathrm{C}$ & -2 & $\mathrm{~N} / \mathrm{C}$ & $\mathrm{N} / \mathrm{C}$ \\
\hline NM_012716 & Slc16a1 & $\begin{array}{l}\text { Solute carrier family } 16 \text { (monocarboxylic acid } \\
\text { transporters), member } 1\end{array}$ & SLC16A1 & -3 & $\mathrm{~N} / \mathrm{C}$ & -2 & $\mathrm{~N} / \mathrm{C}$ & $\mathrm{N} / \mathrm{C}$ \\
\hline NM_013177 & Got2 & $\begin{array}{l}\text { Glutamate oxaloacetate transaminase } 2 \\
\text { mitochondrial }\end{array}$ & GOT2 & -2 & $\mathrm{~N} / \mathrm{C}$ & $\mathrm{N} / \mathrm{C}$ & N/C & -2 \\
\hline NM_012737 & Apoa4 & Apolipoprotein A-IV & APOA4 & $\mathrm{N} / \mathrm{C}$ & -9 & -3 & -4 & $\mathrm{~N} / \mathrm{C}$ \\
\hline NM_053923 & Pik3c2g & $\begin{array}{l}\text { Phosphatidylinositol 3-kinase, C2 domain containing, } \\
\text { gamma polypeptide }\end{array}$ & PIK3C2G & -3 & $\mathrm{~N} / \mathrm{C}$ & -3 & -3 & $\mathrm{~N} / \mathrm{C}$ \\
\hline NM_024484 & Alas1 & Aminolevulinic acid synthase 1 & ALAS1 & -3 & $\mathrm{~N} / \mathrm{C}$ & -3 & -3 & 2 \\
\hline NM_019185 & Gata6 & GATA binding protein 6 & GATA6 & -3 & $\mathrm{~N} / \mathrm{C}$ & -3 & -4 & $\mathrm{~N} / \mathrm{C}$ \\
\hline NM_053328 & Bhlhb2 & Basic helix-loop-helix domain containing, class B2 & BHLHB2 & -2 & $\mathrm{~N} / \mathrm{C}$ & -4 & N/C & $\mathrm{N} / \mathrm{C}$ \\
\hline $\begin{array}{l}\text { XM_001076124/// } \\
\text { XM_001076147/// } \\
\text { XM_001076171/// } \\
\text { XM_341825 }\end{array}$ & Prodh2 & Proline dehydrogenase (oxidase) 2 & $\mathrm{PRODH} 2$ & -3 & $\mathrm{~N} / \mathrm{C}$ & $\mathrm{N} / \mathrm{C}$ & -3 & $\mathrm{~N} / \mathrm{C}$ \\
\hline NM_147206 & Cyp3a13 & $\begin{array}{l}\text { Cytochrome P450, family 3, subfamily a, polypeptide } \\
13\end{array}$ & CYP3A4 & N/C & -9 & -606 & -610 & $\mathrm{~N} / \mathrm{C}$ \\
\hline
\end{tabular}

$\mathrm{N} / \mathrm{C}$ indicates no change in gene expression for that treatment.

been shown to be up-regulated in colon adenocarcinoma [32], colorectal cancer [33] and breast cancer [34]. Additionally, increased expression of Psat1 in colorectal cancer and breast cancer is associated with a poor regression of tumor metastases following therapy $[33,34]$. The increase expression of Psat1 following TCDD, PCB126 and PCB153 treatments suggests that its response is not specific to DLCs. The identification of unique gene expression profiles in Sprague-Dawley rats exposed to DLCs (TCDD or PCB126) versus non-
DLCs (PCB153) corroborates similar observations previously reported in ovariectomized C57BL/6 mice [35].

From the hepatic gene expression signatures of PCB126 and TCDD, 41 genomic biomarkers were identified that are shared by both compounds, following 13 and 52 weeks of exposure (Table 4). The observation that these 41 genomic biomarkers are shared by two AhR ligands suggests that differential expression of these genes requires AhR activation. Of the $41 \mathrm{AhR}$-ligand genomic biomarkers, 30 exhibited a 2 -fold or greater change in 
expression $24 \mathrm{~h}$ post-exposure to an acute dose of TCDD, as determined by real-time qPCR. In addition, approximately $40 \%$ of these genes have shown a 2 -fold change in expression following acute exposure to TCDD in other studies conducted on female and/or male Sprague-Dawley rats [14,27], adding further support that these genomic biomarkers represent time-independent primary responses in gene expression to AhR ligands. Ten of the AhR genomic biomarkers resulted in a less than 2-fold change following acute exposure to TCDD, however, 9 of these biomarkers exhibited a similar trend in the up or down regulation observed following subchronic and chronic exposure to TCDD and PCB126 (Table 4). Furthermore, other microarray studies have shown that following an acute exposure to TCDD, the majority of these genomic biomarkers exhibit a similar response as that seen in our study $[14,29,30]$, thus providing further evidence for their roles as biomarkers.

Seven of the 41 genomic biomarkers are members of the "AhR gene battery" which are a group of genes known to be regulated by the AhR [36]. Genomic biomarker genes which fall into this category include CYP1a1, CYP1a2 (cytochrome P450 1A2), CYP1b1, Nqo1, Ugt1a6, Ugt1A7 and Aldh3a1 (aldehyde dehydrogenase 3A1). More novel genes included among the 41 genomic biomarkers include genes involved in trafficking/transport (Cadps, Exoc3, Serpina7, Slc13a3 and Slc29a1), cell adhesion (Ceacam10 and Enpp2), cell signaling (Ptprd, Ptprn and Trib3) and development/differentiation (Enpp3 and Srd5a1). Enpp2 (Ectonucleotide pyrophosphatase/phosphodiesterase 2; also known as autotaxin), a tumor cell motility stimulating factor [37], was up-regulated following TCDD and PCB126 exposure. This agrees with previous observations implicating Enpp 2 as being one of the most commonly upregulated genes in cancer cells and being widely involved in tumor progression, invasion and metastasis [38]. Ptprd (Receptor-type tyrosine-protein phosphatase delta), a protein tyrosine phosphatase, has been identified as a tumor suppressor $[39,40]$ whose expression is down-regulation in breast, colon and glioblastoma tumors [39,41]. The downregulation of Ptprd following TCDD and PCB126 exposure likely contributes to the neoplastic effects of the compounds. Trib3 (Tribbles homolog 3 (Drosophila)) is a regulatory protein which has been shown to be up-regulated following stressful conditions [42,43], consistent with its up-regulation following TCDD and PCB126 exposure.

Twenty-five of the 41 AhR-ligand genomic biomarkers contained one or more putative DRE within $5000 \mathrm{bp}$ upstream and 1000 bp downstream from the transcriptional start site (Table 4). However, genes such as Cyp3a13 (cytochrome P450 3A13), Ces3 (carboxylesterase 3) and Serpina 7 (serine (or cysteine) peptidase inhibitor, clade A (alpha-1 antiproteinase, antitrypsin), member 7) did not contain a putative DRE in the region examined $(-5000 \mathrm{bp}$ to $+1000 \mathrm{bp})$, suggesting that an activated AhR may not directly bind to these genes. Interestingly, even though Cyp3a13, Ces3 and Serpina 7 do not contain any DREs in their promoter region, their acute sensitivity to TCDD has been previously shown to be dependent on a functional AhR [13]. This indicates that the presence or lack of a DRE in the promoter region does not solely determine the response of a gene following TCDD exposure; it is also possible that a DRE located outside the region examined here is able to influence gene expression.

In order to relate changes in gene expression to the observed hepatotoxicity, the 52 week hepatic gene expression profiles from TCDD and PCB126 treated rats were compared to the expression profiles from previously published studies [22,24] that examined hepatic neoplastic lesions similar to those observed in the NTP studies. Through this approach, an attempt was made to identify common genes which may play a role in the development and progression of the neoplastic effects observed with DLCs. This comparison identified 24, 17 and 7 genes which were differentially expressed with exposure to DLCs and human ICC, human HCA and rat HCA, respectively (Tables 5 and 6). Interestingly, of the genes common to both DLC exposure and the examined disease states, Alas1, Cadps (Ca2+-dependent secretion activator), Cyp3a13, Enpp2, Pik3c2g (phosphatidylinositol 3kinase, C2 domain containing, gamma polypeptide) and Trib3 were also present among the 41 time independent AhR genomic biomarkers. For both of the HCA and ICC studies there were genes which did not overlap between the similar disease states which is likely due to inter-individual differences in the tumor micro-environment, environmental conditions and other genetic components.

The genes Gata6 and Timp3 were down-regulated in both of the human ICC expression profiles and following TCDD exposure. Gata6 was also down-regulated following PCB126 exposure and in the human HCA expression profile. Additionally, the genes Bhlhb2, Agt and Gata6 were down-regulated in the ICC and HCA disease states and following exposure to DLCs. Gata6 is a zinc finger transcription factors which can regulate gene expression and cell cycle progression $[44,45]$. Expression of Gata6 is significantly depressed in most human adrenocortical tumors $[46,47]$ and it has been hypothesized that decreased expression of Gata6 may be an important event for the escape of tumor cells from normal control mechanisms [48]. Timp3 is a matrix metalloproteinase with proapoptotic activity [49] whose expression is significantly lower in human cholangiocarcinomas [50]. It has been suggested that Timp3 may serve as a tumor suppressor gene in cholangiocarcinoma [50]. Bhlhb2 (also known as Dec1) is a hypoxiainduced gene whose expression is elevated in several 
malignant tumors [51-53]. The down-regulation of Bhlhb2 in HCA, ICC and following TCDD exposure suggest that these tumor micro-environments are not hypoxic. Agt, is a known precursor of angiotensin I and has shown antitumor effects in vitro [54] and in vivo [55] by inducing apoptosis and decreasing endothelial cell proliferation [56]. The down-regulation of Agt in HCA, ICC and following TCDD exposure likely contributes to the formation of neoplastic lesions.

It should be noted that of the 50 genes shared by the $52-$ week gene expression data (TCDD, PCB126, and PCB153) and gene expression data from the published reports of ICC and HCA, only 4 genes (Got2, Ugcg, Stmn1 and Alas1) were found to be differentially expressed by the non-DLC PCB153. Gene expression of Got2 (glutamicoxaloacetic transaminase 2, mitochondrial (aspartate aminotransferase 2), a mitochondrial enzyme involved in energy transduction [57], was down-regulated in the PCB153 and human HCA expression profiles while Ugcg (UDP-glucose ceramide glucosyltransferase), an enzyme involved in glycosphingolipid biosynthesis [58], gene expression was up-regulated in these two expression profiles. Stmn1 (stathmin 1), a cellular protein involved in mictotubule destabilization [59], is over expressed in a wide variety of human cancers including liver, breast, lung and prostate cancer [60-63]. Stmn1 was up-regulated in the TCDD, PCB153 and human HCA expression profiles suggesting that while it is a good marker for different types of human cancer, it may not be a valid biomarker for DLC exposure in Sprague Dawley rats. Gene expression of Alas1, an enzyme involved in heme biosynthesis [64], was down-regulated in the TCDD, PCB126 and human HCA profiles but up-regulated in the PCB153 expression profile, suggesting that down-regulation of Alas1 may promote tumor development.

\section{Conclusions}

Toxicogenomic analysis has identified hepatic genomic biomarkers of exposure to the AhR ligands, TCDD and PCB126; and the non-dioxin-like compound, PCB153. From these genomic biomarkers, time-independent hepatic gene expression signatures were constructed that are unique to TCDD, PCB126 and PCB153. In addition to identifying gene expression signatures for the dioxin-like compounds TCDD and PCB126, 41 common genomic biomarkers were identified which are shared by these AhR ligands. These 41 common genomic biomarkers may serve as biomarkers of exposure to other AhR ligands and can be used in the risk assessment of other environmental toxins believed to exert their effect through AhR activation. Together, the data collected in this study can serve to guide future investigations in assessing risk of dioxin-like compounds and elucidating the mechanisms of action by which dioxin-like compounds induce their hepatotoxic and carcinogenic effects.

\section{Additional material}

\begin{abstract}
Additional file 1: Rat primer sequences used for real-time qPCR
analysis. Oligonucleotide sequences for the forward and reverse primers used for real-time qPCR.

Additional file 2: Microarray gene expression following $\mathbf{5 2}$ weeks of chronic p.o. exposure to $\mathbf{3 0} \mathbf{n g} / \mathbf{k g} / \mathbf{d a y}$ PCB126 A list of the 52 genes differentially expressed following 52 weeks of chronic exposure to $30 \mathrm{ng} /$ $\mathrm{kg} /$ day PCB126. A gene was considered to be differentially expressed if it displayed a gene expression fold change of 2 or greater.
\end{abstract}

Additional file 3: Microarray gene expression following 52 weeks of chronic p.o. exposure to $\mathbf{3 0 0} \mathbf{n g} / \mathbf{k g} /$ day PCB126 A list of the 128 genes differentially expressed following 52 weeks of chronic exposure to $300 \mathrm{ng} / \mathrm{kg} /$ day PCB126. A gene was considered to be differentially expressed if it displayed a gene expression fold change of 2 or greater.

Additional file 4: Microarray gene expression following 52 weeks of chronic p.o. exposure to $1000 \mathbf{~ n g} / \mathbf{k g} /$ day PCB126 A list of the 216 genes differentially expressed following 52 weeks of exposure to 1000 $\mathrm{ng} / \mathrm{kgday}$ PCB126. A gene was considered to be differentially expressed if it displayed a gene expression fold change of 2 or greater.

Additional file 5: Microarray gene expression following 13 weeks of subchronic p.o. exposure to $\mathbf{1 0 0} \mathbf{n g} / \mathbf{k g} /$ day TCDD A list of the 103 genes differentially expressed following 13 weeks of subchronic exposure to $100 \mathrm{ng} / \mathrm{kg} /$ day TCDD. A gene was considered to be differentially expressed if it displayed a gene expression fold change of 2 or greater.

Additional file 6: Microarray gene expression following 52 weeks of chronic p.o. exposure to $\mathbf{1 0 0} \mathbf{n g} / \mathbf{k g} /$ day TCDD A list of the 299 genes differentially expressed genes following 52 weeks of chronic exposure to $100 \mathrm{ng} / \mathrm{kg} /$ day TCDD. A gene was considered to be differentially expressed if it displayed a gene expression fold change of 2 or greater.

Additional file 7: Microarray gene expression following 13 weeks of subchronic p.o. exposure to $1000 \mathrm{ng} / \mathbf{k g} /$ day PCB126 A list of the 371 genes differentially expressed genes following 13 weeks of subchronic exposure to $1000 \mathrm{ng} / \mathrm{kg} /$ day PCB126. A gene was considered to be differentially expressed if it displayed a gene expression fold change of 2 or greater.

Additional file 8: Microarray gene expression following 13 weeks of subchronic p.o. exposure to $\mathbf{1 0 0 0} \boldsymbol{\mu} \mathbf{g} / \mathbf{k g} / \mathbf{d a y}$ PCB153 A list of the 39 genes differentially expressed following 13 weeks of subchronic exposure to $1000 \mu \mathrm{g} / \mathrm{kg} /$ day PCB153. A gene was considered to be differentially expressed if it displayed a gene expression fold change of 2 or greater.

Additional file 9: Microarray gene expression following $\mathbf{5 2}$ weeks of chronic p.o. exposure to $1000 \mu \mathbf{g} / \mathbf{k g} /$ day PCB153 A list of the 47 genes differentially expressed following 52 weeks of chronic exposure to $1000 \mu \mathrm{g} / \mathrm{kg} /$ day PCB153. A gene was considered to be differentially expressed if it displayed a gene expression fold change of 2 or greater.

\section{Acknowledgements}

We would like to acknowledge Leighton Stein and the Gene Expression Facility at Roswell Park Cancer Institute, Buffalo, NY. These studies were supported in part by National Institute of Environmental Health Sciences (NIEHS) ES09440 (JRO), the IRCAF Program University at Buffalo (JRO), and the Environment and Society Institute, University at Buffalo (JRO). The content is solely the authors' responsibility and does not necessarily represent official views of NIEHS.

\section{Author details}

${ }^{1}$ Department of Pharmacology and Toxicology, School of Medicine and Biomedical Sciences, University at Buffalo, Buffalo, New York 14214, USA. ${ }^{2}$ School of Pharmacy and Molecular and Environmental Toxicology Center, University of Wisconsin, Madison, Wisconsin 53705, USA. 


\section{Authors' contributions}

Microarray analysis was performed by BJO and CMV. Real-time GPCR analysis was performed by CAE. Phenotypic anchoring was performed by BJO and CAE. The project was conceived and designed by JRO. BJO wrote the first draft of the manuscript, which all authors edited and approved.

Received: 10 June 2010 Accepted: 19 October 2010 Published: 19 October 2010

\section{References}

1. Birnbaum LS, Tuomisto J: Non-carcinogenic effects of TCDD in animals. Food Additives \& Contaminants 2000, 17(4):275-288.

2. Safe SH: Polychlorinated biphenyls (PCBs): environmental impact, biochemical and toxic responses, and implications for risk assessment. Critical Reviews in Toxicology 1994, 24(2):87-149.

3. Sweeney MH, Mocarelli P: Human health effects after exposure to 2,3,7,8TCDD. Food Additives \& Contaminants 2000, 17(4):303-316.

4. NTPa: NTP technical report on the toxicology and carcinogenesis studies of 2,3,7,8-tetrachlorodibenzo-p-dioxin (TCDD) (CAS No. 1746-01-6) in female Harlan Sprague-Dawley rats (Gavage Studies). National Toxicology Program technical report series 2006, 521: 4-232.

5. NTPb: NTP toxicology and carcinogenesis studies of 3,3,4,4,5pentachlorobiphenyl (PCB 126) (CAS No. 57465-28-8) in female Harlan Sprague-Dawley rats (Gavage Studies). National Toxicology Program technical report series 2006, 520: 4-246.

6. Kociba RJ, Keyes DG, Beyer JE, Carreon RM, Wade CE, Dittenber DA, Kalnins RP, Frauson LE, Park CN, Barnard SD, et al: Results of a two-year chronic toxicity and oncogenicity study of 2,3,7,8-tetrachlorodibenzo-pdioxin in rats. Toxicol Appl Pharmacol 1978, 46(2):279-303.

7. Walker NJ, Crockett PW, Nyska A, Brix AE, Jokinen MP, Sells DM, Hailey JR, Easterling $\mathrm{M}$, Haseman JK, Yin $\mathrm{M}$, et al: Dose-additive carcinogenicity of a defined mixture of "dioxin-like compounds". Environmental Health Perspectives 2005, 113(1):43-48.

8. NTPC: NTP technical report on the toxicology and carcinogenesis studies

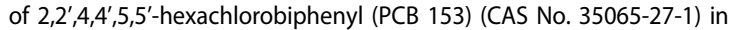
female Harlan Sprague-Dawley rats (Gavage studies). National Toxicology Program technical report series 2006, 529: 4-168.

9. Tan Z, Chang X, Puga A, Xia Y: Activation of mitogen-activated protein kinases (MAPKs) by aromatic hydrocarbons: role in the regulation of aryl hydrocarbon receptor (AHR) function. Biochemical pharmacology 2002, 64(5-6):771-780.

10. Tijet N, Boutros PC, Moffat ID, Okey AB, Tuomisto J, Pohjanvirta R: Aryl hydrocarbon receptor regulates distinct dioxin-dependent and dioxinindependent gene batteries. Mol Pharmacol 2006, 69(1):140-153.

11. Gonzalez FJ, Fernandez-Salguero P: The aryl hydrocarbon receptor: studies using the AHR-null mice. Drug metabolism and disposition: the biological fate of chemicals 1998, 26(12):1194-1198.

12. Fernandez-Salguero PM, Hilbert DM, Rudikoff S, Ward JM, Gonzalez FJ: Arylhydrocarbon receptor-deficient mice are resistant to $2,3,7,8$ tetrachlorodibenzo-p-dioxin-induced toxicity. Toxicology and applied pharmacology 1996, 140(1):173-179.

13. Ovando BJ, Vezina CM, McGarrigle BP, Olson JR: Hepatic gene downregulation following acute and subchronic exposure to 2,3,7,8tetrachlorodibenzo-p-dioxin. Toxicol Sci 2006, 94(2):428-438.

14. Boverhof DR, Burgoon LD, Tashiro C, Sharratt B, Chittim B, Harkema JR, Mendrick DL, Zacharewski TR: Comparative toxicogenomic analysis of the hepatotoxic effects of TCDD in Sprague Dawley rats and C57BL/6 mice. Toxicol Sci 2006, 94(2):398-416.

15. Tuomisto JT, Viluksela M, Pohjanvirta $R$, Tuomisto J: The AH receptor and a novel gene determine acute toxic responses to TCDD: segregation of the resistant alleles to different rat lines. Toxicology and applied pharmacology 1999, 155(1):71-81.

16. Pohjanvirta R, Wong JM, Li W, Harper PA, Tuomisto J, Okey AB: Point mutation in intron sequence causes altered carboxyl-terminal structure in the aryl hydrocarbon receptor of the most 2,3,7,8-tetrachlorodibenzop-dioxin-resistant rat strain. Molecular pharmacology 1998, 54(1):86-93.

17. Vezina CM, Walker NJ, Olson JR: Subchronic exposure to TCDD, PeCDF, PCB126, and PCB153: effect on hepatic gene expression. Environ Health Perspect 2004, 112(16):1636-1644.
18. Van den Berg M, Birnbaum L, Denison MS, De Vito M, Farland W, Feeley M, Fiedler H, Hakansson H, Hanberg A, Haws L, et al: The 2005 World Health Organization Re-evaluation of Human and Mammalian Toxic Equivalency Factors for Dioxins and Dioxin-like Compounds. Toxicological Sciences 2006, 93(2):223-241.

19. Saeed Al, Sharov V, White J, Li J, Liang W, Bhagabati N, Braisted J, Klapa M, Currier T, Thiagarajan M, et al: TM4: a free, open-source system for microarray data management and analysis. Biotechniques 2003, 34(2):374-378

20. Rozen S, Skaletsky H: Primer3 on the www for general users and for biologist programmers. Methods Mol Biol 2000, 132:365-386.

21. Cartharius K, Frech K, Grote K, Klocke B, Haltmeier M, Klingenhoff A, Frisch M, Bayerlein M, Werner T: MatInspector and beyond: promoter analysis based on transcription factor binding sites. Bioinformatics 2005, 21(13):2933-2942.

22. Yim SH, Ward JM, Dragan Y, Yamada A, Scacheri PC, Kimura S, Gonzalez FJ: Microarray analysis using amplified mRNA from laser capture microdissection of microscopic hepatocellular precancerous lesions and frozen hepatocellular carcinomas reveals unique and consistent gene expression profiles. Toxicologic pathology 2003, 31(3):295-303.

23. Boyault S, Rickman DS, de Reynies A, Balabaud C, Rebouissou S, Jeannot E, Herault A, Saric J, Belghiti J, Franco D, et al: Transcriptome classification of $\mathrm{HCC}$ is related to gene alterations and to new therapeutic targets. Hepatology 2007, 45(1):42-52.

24. Obama K, Ura K, Li M, Katagiri T, Tsunoda T, Nomura A, Satoh S, Nakamura Y, Furukawa Y: Genome-wide analysis of gene expression in human intrahepatic cholangiocarcinoma. Hepatology Baltimore, Md 2005, 41(6):1339-1348.

25. Miller G, Socci ND, Dhall D, D'Angelica M, DeMatteo RP, Allen PJ, Singh B, Fong Y, Blumgart $L H$, Klimstra DS, et al: Genome wide analysis and clinical correlation of chromosomal and transcriptional mutations in cancers of the biliary tract. J Exp Clin Cancer Res 2009, 28:62.

26. Tong W, Cao X, Harris S, Sun H, Fang H, Fuscoe J, Harris A, Hong H, Xie Q, Perkins $R$, et al: ArrayTrack-supporting toxicogenomic research at the $U$. S. Food and Drug Administration National Center for Toxicological Research. Environmental Health Perspectives 2003, 111(15):1819-1826.

27. Fletcher N, Wahlstrom D, Lundberg R, Nilsson CB, Nilsson KC, Stockling K, Hellmold H, Hakansson H: 2,3,7,8-Tetrachlorodibenzo-p-dioxin (TCDD) alters the mRNA expression of critical genes associated with cholesterol metabolism, bile acid biosynthesis, and bile transport in rat liver: a microarray study. Toxicol Appl Pharmacol 2005, 207(1):1-24.

28. N'Jai A, Boverhof DR, Dere E, Burgoon LD, Tan YS, Rowlands JC, Budinsky RA, Stebbins KE, Zacharewski TR: Comparative temporal toxicogenomic analysis of TCDD- and TCDF-mediated hepatic effects in immature female C57BL/6 mice. Toxicol Sci 2008, 103(2):285-297.

29. Boutros PC, Yan R, Moffat ID, Pohjanvirta R, Okey AB: Transcriptomic responses to 2,3,7,8-tetrachlorodibenzo-p-dioxin (TCDD) in liver: comparison of rat and mouse. BMC Genomics 2008, 9:419.

30. Franc MA, Moffat ID, Boutros PC, Tuomisto JT, Tuomisto J, Pohjanvirta R, Okey AB: Patterns of dioxin-altered mRNA expression in livers of dioxinsensitive versus dioxin-resistant rats. Arch Toxicol 2008, 82(11):809-830,

31. Kopec AK, Boverhof DR, Burgoon LD, Ibrahim-Aibo D, Harkema JR, Tashiro C, Chittim B, Zacharewski TR: Comparative toxicogenomic examination of the hepatic effects of PCB126 and TCDD in immature, ovariectomized C57BL/6 mice. Toxicol Sci 2008, 102(1):61-75.

32. Ojala P, Sundstrom J, Gronroos JM, Virtanen E, Talvinen $K$, Nevalainen TJ: mRNA differential display of gene expression in colonic carcinoma. Electrophoresis 2002, 23(11):1667-1676.

33. Vie N, Copois V, Bascoul-Mollevi C, Denis V, Bec N, Robert B, Fraslon C, Conseiller E, Molina F, Larroque C, et al: Overexpression of phosphoserine aminotransferase PSAT1 stimulates cell growth and increases chemoresistance of colon cancer cells. Mol Cancer 2008, 7:14.

34. Martens JW, Nimmrich I, Koenig T, Look MP, Harbeck N, Model F, Kluth A, Bolt-de Vries J, Sieuwerts AM, Portengen $\mathrm{H}$, et al: Association of DNA methylation of phosphoserine aminotransferase with response to endocrine therapy in patients with recurrent breast cancer. Cancer Res 2005, 65(10):4101-4117.

35. Kopec AK, Burgoon LD, Ibrahim-Aibo D, Mets BD, Tashiro C, Potter D, Sharratt B, Harkema JR, Zacharewski TR: PCB153-elicited hepatic responses 
in the immature, ovariectomized C57BL/6 mice: comparative toxicogenomic effects of dioxin and non-dioxin-like ligands. Toxicol Appl Pharmacol 2010, 243(3):359-371.

36. Nebert DW, Roe AL, Dieter MZ, Solis WA, Yang Y, Dalton TP: Role of the aromatic hydrocarbon receptor and [Ah] gene battery in the oxidative stress response, cell cycle control, and apoptosis. Biochem Pharmacol 2000, 59(1):65-85.

37. Umezu-Goto M, Kishi Y, Taira A, Hama K, Dohmae N, Takio K, Yamori T, Mills GB, Inoue K, Aoki J, et al: Autotaxin has lysophospholipase D activity leading to tumor cell growth and motility by lysophosphatidic acid production. J Cell Biol 2002, 158(2):227-233.

38. Xu XY, Yang GH, Zhang HL, Prestwich GD: Evaluating dual activity LPA receptor pan-antagonist/autotaxin inhibitors as anti-cancer agents in vivo using engineered human tumors. Prostag Oth Lipid M 2009, 89(3-4):140-146.

39. Chan TA, Glockner S, Yi JM, Chen W, Van Neste L, Cope L, Herman JG, Velculescu V, Schuebel KE, Ahuja N, et al: Convergence of mutation and epigenetic alterations identifies common genes in cancer that predict for poor prognosis. PLoS Med 2008, 5(5):e114.

40. Chan TA, Heguy A: The protein tyrosine phosphatase receptor $D, a$ broadly inactivated tumor suppressor regulating STAT function. Cell Cycle 2009, 8(19):3063-3064.

41. Veeriah S, Brennan C, Meng SS, Singh B, Fagin JA, Solit DB, Paty PB, Rohle D, Vivanco I, Chmielecki J, et al: The tyrosine phosphatase PTPRD is a tumor suppressor that is frequently inactivated and mutated in glioblastoma and other human cancers. P Natl Acad Sci USA 2009, 106(23):9435-9440.

42. Ord D, Ord T: Characterization of human NIPK (TRB3, SKIP3) gene activation in stressful conditions. Biochem Bioph Res Co 2005, 330(1):210-218.

43. Corcoran CA, Luo XQ, He Q, Jiang CY, Huang Y, Sheikh MS: Genotoxic and endoplasmic reticulum stresses differentially regulate TRB3 expression. Cancer Biol Ther 2005, 4(10):1063-1067.

44. Orkin SH: GATA-binding transcription factors in hematopoietic cells. Blood 1992, 80(3):575-581.

45. Heikinheimo $M$, Ermolaeva $M$, Bielinska M, Rahman NA, Narita N, Huhtaniemi IT, Tapanainen JS, Wilson DB: Expression and hormonal regulation of transcription factors GATA- 4 and GATA- 6 in the mouse ovary. Endocrinology 1997, 138(8):3505-3514.

46. Kiiveri S, Liu J, Heikkila P, Arola J, Lehtonen E, Voutilainen R, Heikinheimo M: Transcription factors GATA-4 and GATA-6 in human adrenocortical tumors. Endocr Res 2004, 30(4):919-923.

47. Kiiveri S, Siltanen S, Rahman N, Bielinska M, Lehto VP, Huhtaniemi IT, Muglia $L$, Wilson DB, Heikinheimo M: Reciprocal changes in the expression of transcription factors GATA- 4 and GATA- 6 accompany adrenocortical tumorigenesis in mice and humans. Mol Med 1999, 5(7):490-501.

48. Viger RS, Guittot SM, Anttonen M, Wilson DB, Heikinheimo M: Role of the GATA family of transcription factors in endocrine development, function, and disease. Mol Endocrinol 2008, 22(4):781-798.

49. Jiang Y, Goldberg ID, Shi YE: Complex roles of tissue inhibitors of metalloproteinases in cancer. Oncogene 2002, 21(14):2245-2252.

50. Selaru FM, Olaru AV, Kan T, David S, Cheng Y, Mori Y, Yang J, Paun B, Jin Z, Agarwal $R$, et al: MicroRNA-21 is overexpressed in human cholangiocarcinoma and regulates programmed cell death 4 and tissue inhibitor of metalloproteinase 3. Hepatology 2009, 49(5):1595-1601.

51. Chakrabarti J, Turley H, Campo L, Han C, Harris AL, Gatter KC, Fox SB: The transcription factor DEC1 (stra13, SHARP2) is associated with the hypoxic response and high tumour grade in human breast cancers. $\mathrm{Br} J$ Cancer 2004, 91(5):954-958

52. Giatromanolaki A, Koukourakis Ml, Sivridis E, Turley H, Wykoff CC, Gatter KC, Harris AL: DEC1 (STRA13) protein expression relates to hypoxia- inducible factor 1-alpha and carbonic anhydrase-9 overexpression in non-small cell lung cancer. J Pathol 2003, 200(2):222-228.

53. Li Y, Zhang H, Xie M, Hu M, Ge S, Yang D, Wan Y, Yan B: Abundant expression of Dec1/stra13/sharp2 in colon carcinoma: its antagonizing role in serum deprivation-induced apoptosis and selective inhibition of procaspase activation. Biochem J 2002, 367(Pt 2):413-422.

54. Celerier J, Cruz A, Lamande N, Gasc JM, Corvol P: Angiotensinogen and its cleaved derivatives inhibit angiogenesis. Hypertension 2002, 39(2):224-228.
55. Vincent F, Bonnin P, Clemessy M, Contreres JO, Lamande N, Gasc JM, Vilar J, Hainaud P, Tobelem G, Corvol P, et al: Angiotensinogen delays angiogenesis and tumor growth of hepatocarcinoma in transgenic mice. Cancer Res 2009, 69(7):2853-2860.

56. Brand M, Lamande N, Larger E, Corvol P, Gasc JM: Angiotensinogen impairs angiogenesis in the chick chorioallantoic membrane. J Mol Med 2007, 85(5):451-460.

57. Hirsch D, Stahl A, Lodish HF: A family of fatty acid transporters conserved from mycobacterium to man. Proc Natl Acad Sci USA 1998, 95(15):8625-8629.

58. Yamashita T, Wada R, Sasaki T, Deng C, Bierfreund U, Sandhoff K, Proia RL: A vital role for glycosphingolipid synthesis during development and differentiation. Proc Natl Acad Sci USA 1999, 96(16):9142-9147.

59. Rubin $\mathrm{Cl}$, Atweh GF: The role of stathmin in the regulation of the cell cycle. J Cell Biochem 2004, 93(2):242-250.

60. Hsieh SY, Huang SF, Yu MC, Yeh TS, Chen TC, Lin YJ, Chang CJ, Sung CM, Lee YL, Hsu CY: Stathmin1 Overexpression Associated With Polyploidy, Tumor-Cell Invasion, Early Recurrence, and Poor Prognosis in Human Hepatoma. Mol Carcinogen 2010, 49(5):476-487.

61. Golouh R, Cufer T, Sadikov A, Nussdorfer P, Usher PA, Brunner N, Schmitt M, Lesche R, Maier $S$, Timmermans $M$, et al: The prognostic value of Stathmin-1, S100A2, and SYK proteins in ER-positive primary breast cancer patients treated with adjuvant tamoxifen monotherapy: an immunohistochemical study. Breast Cancer Res Tr 2008, 110(2):317-326.

62. Ngo TTB, Peng T, Liang XJ, Akeju O, Pastorino S, Zhang W, Kotliarov $Y$, Zenklusen JC, Fine HA, Maric D, et al: The $1 \mathrm{p}$-encoded protein stathmin and resistance of malignant gliomas to nitrosoureas. J Nat/ Cancer / 2007, 99(8):639-652.

63. Friedrich B, Gronberg $H$, Landstrom M, Gullberg M, Bergh A: Differentiation-Stage Specific Expression of Oncoprotein-18 in Human and Rat Prostatic Adenocarcinoma. Prostate 1995, 27(2):102-109.

64. Furuyama K, Kaneko K, Vargas PD: Heme as a magnificent molecule with multiple missions: heme determines its own fate and governs cellular homeostasis. Tohoku J Exp Med 2007, 213(1):1-16.

doi:10.1186/1471-2164-11-583

Cite this article as: Ovando et al: Toxicogenomic analysis of exposure to TCDD, PCB126 and PCB153: identification of genomic biomarkers of exposure to AhR ligands. BMC Genomics 2010 11:583.

\section{Submit your next manuscript to BioMed Central and take full advantage of:}

- Convenient online submission

- Thorough peer review

- No space constraints or color figure charges

- Immediate publication on acceptance

- Inclusion in PubMed, CAS, Scopus and Google Scholar

- Research which is freely available for redistribution 